\title{
FISH RESEARCH PROJECT OREGON INVESTIGATIONS INTO THE EARLY LIFE HISTORY OF NATURALLY PRODUCED SPRING CHINOOK SALMON IN THE GRANDE RONDE RIVER BASIN
}

Project Period: 1 September 1997 to 31 August 1998

Annual Progress Report

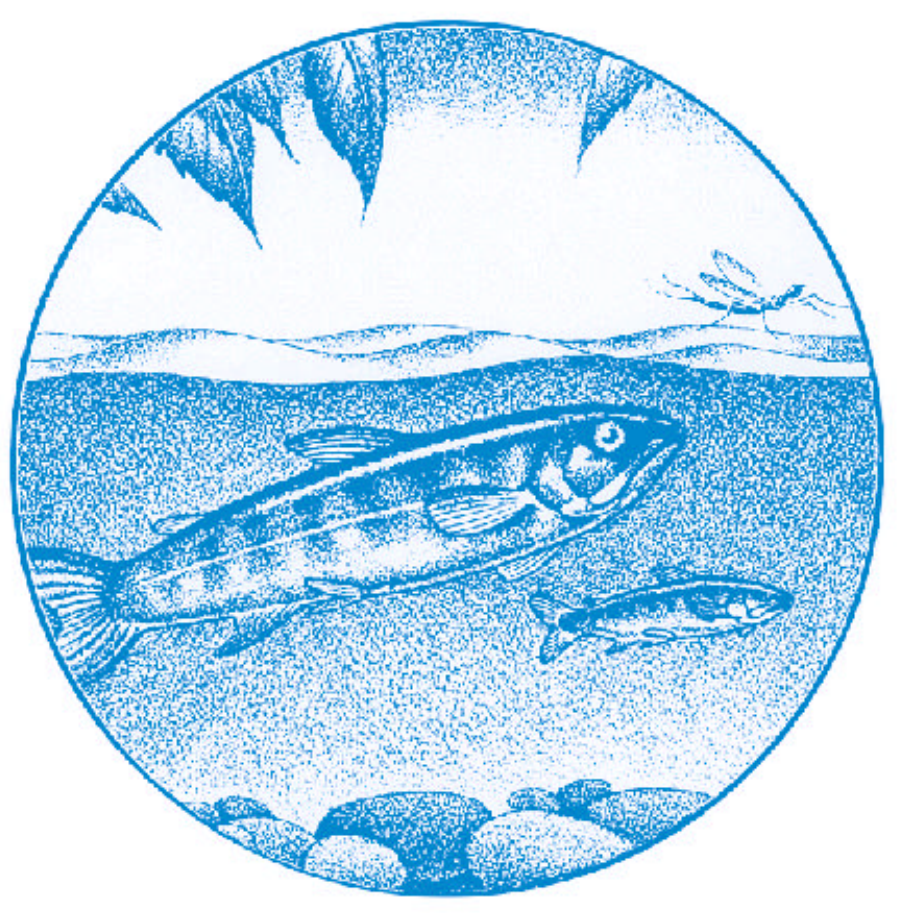

DOE/BP-33299-4 
This report was funded by the Bonneville Power Administration (BPA), U.S. Department of Energy, as part of BPA's program to protect, mitigate, and enhance fish and wildlife affected by the development and operation of hydroelectric facilities on the Columbia River and its tributaries. The views of this report are the author's and do not necessarily represent the views of BPA.

This document should be cited as follows:

Keefe, MaryLouise; J. V. Tranquilli, P. Sankovich, E. S. Van Dyke, B. C. Jonasson, R. W. Carmichael - Oregon Dept. of Fish and Wildlife, 1998, Fish Research Project Oregon Investigations Into The Early Life History Of Naturally

Produced Spring Chinook Salmon In The Grande Ronde River Basin Annual Progress Report, Project Period: 1

September 1997 to 31 August 1998, Report to Bonneville Power Administration, Contract No. 1994BI33299, Project No. 199202604, 62 electronic pages (BPA Report DOE/BP-33299-4)

This report and other BPA Fish and Wildlife Publications are available on the Internet at:

\section{http://www.efw.bpa.gov/cgi-bin/efw/FW/publications.cgi}

For other information on electronic documents or other printed media, contact or write to:

Bonneville Power Administration

Environment, Fish and Wildlife Division

P.O. Box 3621

905 N.E. 11th Avenue

Portland, OR 97208-3621

Please include title, author, and DOE/BP number in the request. 


\title{
FISH RESEARCH PROJECT OREGON
}

\section{INVESTIGATIONS INTO THE EARLY LIFE HISTORY OF NATURALLY PRODUCED SPRING CHINOOK SALMON IN THE GRANDE RONDE RIVER BASIN}

\section{ANNUAL PROGRESS REPORT}

Project Period: 1 September 1997 to 31 August 1998

\author{
Prepared by: \\ MaryLouise Keefe \\ J. Vincent Tranquilli \\ Paul Sankovich \\ Erick S. Van Dyke \\ Brian C. Jonasson \\ Richard W. Carmichael
}

Oregon Department of Fish and Wildlife

La Grande, OR

Funded by

U. S. Department of Energy

Bonneville Power Administration

Environment, Fish and Wildlife

P.O. Box 3621

Portland, OR 97208-3621

Project Number 92-026-04

Contract Number 94B133299 


\begin{abstract}
We determined migration timing and abundance of juvenile spring chinook salmon from three populations in the Grande Ronde River basin. We estimated 6,716 juvenile chinook salmon left upper rearing areas of the Grande Ronde River from July 1997 to June 1998; approximately $6 \%$ of the migrants left in summer, $29 \%$ in fall, $2 \%$ in winter, and $63 \%$ in spring. We estimated 8,763 juvenile chinook salmon left upper rearing areas of Catherine Creek from July 1997 to June 1998; approximately $12 \%$ of the migrants left in summer, $37 \%$ in fall, $21 \%$ in winter, and $29 \%$ in spring. We estimated 8,859 juvenile chinook salmon left the Grande Ronde Valley, located below the upper rearing areas in Catherine Creek and the Grande Ronde River, from October 1997 to June 1998; approximately 99\% of the migrants left in spring. We estimated 15,738 juvenile chinook salmon left upper rearing areas of the Lostine River from July 1997 to April 1998; approximately 3\% of the migrants left in summer, $61 \%$ in fall, $2 \%$ in winter, and $34 \%$ in spring. We estimated 22,754 juvenile spring chinook salmon left the Wallowa Valley, located below the mouth of the Lostine River, from September 1997 to April 1998; approximately $55 \%$ of the migrants left in fall, $5 \%$ in winter, and $40 \%$ in spring.
\end{abstract}

Juvenile chinook salmon PIT-tagged on the upper Grande Ronde River were detected at Lower Granite Dam from 4 April to 26 June 1998, with a median passage date of 1 May. PITtagged salmon from Catherine Creek were detected at Lower Granite Dam from 3 April to 26 June 1998, with a median passage date of 8 May. PIT-tagged salmon from the Lostine River were detected at Lower Granite Dam from 31 March through 26 May 1998, with a median passage date of 28 April. Juveniles tagged as they left the upper rearing areas of the Grande Ronde and Lostine rivers in fall and that overwintered in areas downstream were detected in the hydrosystem at a higher rate than fish tagged during winter in the upper rearing areas, indicating a higher overwinter survival in the downstream areas. Fish from Catherine Creek showed no difference in detection rates between the fall and winter tag groups, indicating similar overwinter survival in the upper and lower rearing areas.

Chinook salmon parr were generally associated with low velocity habitat types during winter in Catherine Creek, and both winter and summer in the Lostine River.

In summer 1997, we PIT-tagged parr on Catherine Creek and the Minam and Imnaha rivers in order to monitor their subsequent migration as smolts through the Snake and Columbia River hydrosystem. We found significant differences among populations in smolt migration timing at Lower Granite Dam in 1998. Fish from Catherine Creek and the Minam and Imnaha rivers were detected in the hydrosystem at rates of $16.4,20.5$, and $28.1 \%$, respectively.

In 1998, we estimated parr abundance and the number of parr produced per redd in Catherine Creek and the Lostine River. We estimated that 429 mature, age 1+ male parr and 13,222 immature, age 0+ parr were present in Catherine Creek in August. An average of 29 mature, age 1+ male parr and 287 immature, age $0+$ parr were produced from each redd constructed in 1996 and 1997, respectively. We estimated that 75 mature, age 1+ male parr and 40,748 immature, age 0+ parr were present in the Lostine River in August. An average of 3 mature, age 1+ male parr and 832 immature, age 0+ parr were produced from each redd constructed in 1996 and 1997, respectively. For every anadromous female spawner in Catherine Creek and the Lostine River in 1998, there were an estimated 13 and 3 mature male parr, respectively. 


\section{CONTENTS}

$\underline{\text { Page }}$

EXECUTIVE SUMMARY ............................................................................ 1

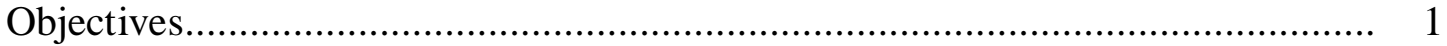

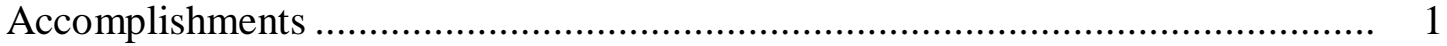

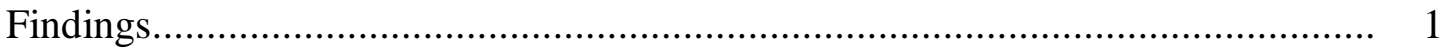

Management Implications and Recommendations...................................... 3

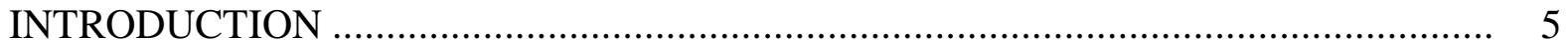

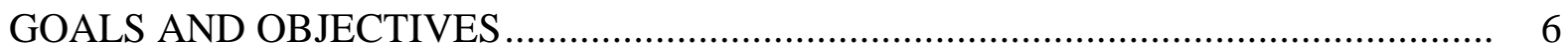

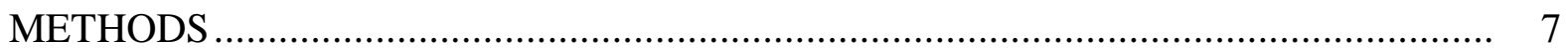

Egg-to-Parr Survival, Abundance, and Age Composition of Parr ....................... 7

In-Basin Migration Timing and Abundance ............................................... 10

Migration Timing and Survival to Lower Granite Dam................................... 14

Juvenile Trapping Studies ...................................................... 14

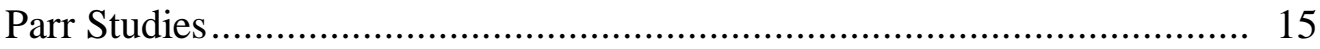

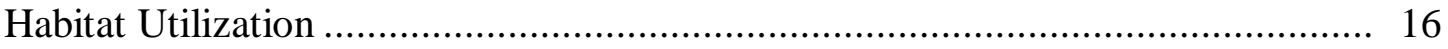

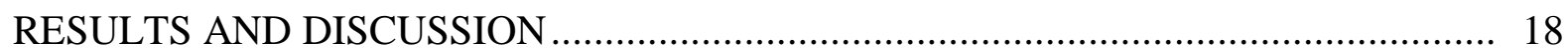

Egg-to-Parr Survival, Abundance, and Age Composition of Parr ...................... 18

In-Basin Migration Timing and Abundance ................................................ 19

Migration Timing and Survival to Lower Granite Dam ................................. 40

Juvenile Trapping Studies ................................................................ 40

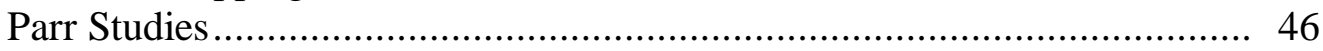

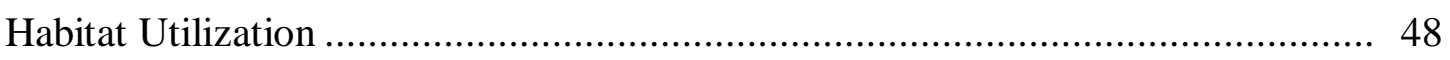

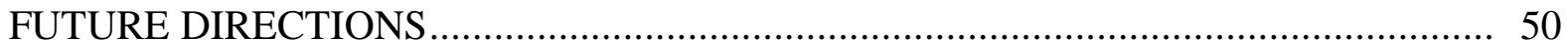

REFERENCES …................................................................................... 51 


\section{FIGURES}

Number

$\underline{\text { Page }}$

1. Locations of fish traps in the Grande Ronde River Basin during the study period

2. Diel pattern observed in capture of juvenile spring chinook salmon at the Wallowa trap during spring

3. Estimated migration timing and abundance of juvenile spring chinook salmon migrants captured by rotary screw traps

4. Length frequency distribution of juvenile spring chinook salmon migrants captured at the upper Grande Ronde River trap by seasonal migration period, during the 1998 migration year.

5. Length frequency distribution of juvenile spring chinook salmon migrants captured at the Catherine Creek trap by seasonal migration period, during the 1998 migration year.

6. Length frequency distribution of juvenile spring chinook salmon migrants captured at the Grande Ronde Valley trap by seasonal migration period, during the 1998 migration year.

7. Length frequency distribution of juvenile spring chinook salmon migrants captured at the Lostine River trap by seasonal migration period, during the 1998 migration year.....

8. Length frequency distribution of juvenile spring chinook salmon migrants captured at the Wallowa Valley trap by seasonal migration period, during the 1998 migration year......

9. Migration timing at Lower Granite Dam for juvenile spring chinook salmon PIT-tagged on the upper Grande Ronde River by tag group, during the 1998 migration year

10. Migration timing at Lower Granite Dam for juvenile spring chinook salmon PIT-tagged on Catherine Creek by tag group, during the 1998 migration year.

11. Migration timing at Lower Granite Dam for juvenile spring chinook salmon PIT-tagged on the Lostine River by tag group, during the 1998 migration year.

12. Migration timing at Lower Granite Dam for juvenile spring chinook salmon PIT-tagged as parr during summer 1997 


\section{TABLES}

Number

Page

1. Dates of tagging and number of chinook salmon parr PIT-tagged on various northeast Oregon streams in 1997 and 1998

2. Results from mark-and-recapture experiments conducted in Catherine Creek and the Lostine River in August 1998

3. Age composition of immature and mature chinook salmon parr sampled in Catherine Creek and the Lostine River in 1998

4. Seasonal catch of juvenile chinook salmon at five trap locations in the Grande Ronde River Basin....

5. Fork lengths of juvenile chinook salmon collected from the upper Grande Ronde River

6. Weights of juvenile chinook salmon collected from the upper

Grande Ronde River

7. Fork lengths of juvenile chinook salmon collected from Catherine Creek........... 25

8. Weights of juvenile chinook salmon collected from Catherine Creek

9. Fork lengths of juvenile chinook salmon collected from the Lostine River

10. Weights of juvenile chinook salmon collected from the Lostine River.

11. Fork lengths and weights of juvenile chinook salmon captured by a rotary screw trap at rkm 299 of the Grande Ronde River, weeks 26 to 48, 1997 and weeks 5 to 22,1998

12. Fork lengths and weights of juvenile chinook salmon captured by a rotary screw trap at rkm 32 of Catherine Creek, weeks 30 to 48, 1997 and weeks 1 to 18,1998 .

13. Fork lengths and weights of juvenile chinook salmon captured by a rotary screw trap at rkm 164 of the Grande Ronde River, weeks 43 to 49, 1997 and weeks 8 to 21,1998

14. Fork lengths and weights of juvenile chinook salmon captured by a rotary screw trap at rkm 3 of the Lostine River, weeks 25 to 52, 1997 and weeks 1 to 18,1998 . 


\section{TABLES (continued)}

Number

Page

15. Fork lengths and weights of juvenile chinook salmon captured by a rotary screw trap at rkm 27 of the Wallowa River, weeks 37 to 52, 1997 and weeks 1 to 21,1998

16. Mean fork lengths by tag group of juvenile spring chinook salmon PIT-tagged on the upper Grande Ronde River, Catherine Creek, and Lostine River and recaptured at the Grande Ronde Valley or Wallowa Valley traps during spring.....

17. Detection rates of juvenile chinook salmon PIT-tagged on the upper Grande Ronde River, Catherine Creek, and the Lostine River by group and dam site during the 1998 migration year

18. Detection rates in 1998 of chinook salmon PIT-tagged as parr on Catherine Creek and the Imnaha and Minam rivers in 1997

19. Density of chinook salmon parr in Catherine Creek and mean water velocity by habitat type during winter 1998

20. Density of chinook salmon parr in the Lostine River and mean water velocity by habitat type during winter 1998

21. Density of chinook salmon parr in the Lostine River and mean water velocity by habitat type during summer 1998 


\section{EXECUTIVE SUMMARY}

\section{Objectives}

1. Document the annual in-basin migration patterns, including abundance, timing, and duration, of juvenile spring chinook salmon in the upper Grande Ronde River, Catherine Creek and the Lostine River.

2. Estimate and compare survival indices from tagging to smolt detection at mainstem Snake and Columbia river dams for juveniles that leave upper river rearing areas at different times of the year.

3. Determine summer and winter habitat utilization and preference of juvenile spring chinook salmon in the upper Grande Ronde River, Catherine Creek, and the Lostine River.

4. Estimate and compare smolt detection rates at mainstem Columbia and Snake River dams for migrants from several local, natural populations in the Grande Ronde River and Imnaha River basins.

5. Document the annual migration patterns for spring chinook salmon juveniles from several local, natural populations in the Grande Ronde River and Imnaha River basins.

6. Determine survival to parr stage for spring chinook salmon in two local, natural populations in the Grande Ronde River Basin.

7. Investigate the significance of alternate life history strategies of spring chinook salmon in two local, natural populations in the Grande Ronde River Basin.

\section{Accomplishments}

We accomplished all of our objectives in 1998 with the following exceptions. Due to a low abundance of spring chinook salmon in the upper Grande Ronde, we PIT-tagged fewer fish than planned during winter sampling. We could not generate egg-to-parr survival estimates for the Catherine Creek and the Lostine River populations because adequate data on female fecundity were not available.

\section{Findings}

In the Grande Ronde River Basin, migration timing and abundance of juvenile spring chinook salmon was determined by operating rotary screw traps in both upper and lower river reaches of the Grande Ronde River and Wallowa River valleys. At the upper Grande Ronde River trap, 3,052 juvenile chinook salmon were captured from 1 July 1997 through 17 June 1998. The catch was expanded to an estimate of 6,716 migrants. Approximately $6 \%$ of the 
migrant population left upper rearing areas in Grande Ronde River during summer, 29\% in fall, $2 \%$ in winter, and $63 \%$ in spring. At the Catherine Creek trap, 3,189 juvenile chinook salmon were captured from 25 July through 9 June 1998 and the catch was expanded to an estimate of 8,763 migrants. Approximately $12 \%$ of the migrant population left upper rearing areas in Catherine Creek during summer, $37 \%$ in fall, $21 \%$ in winter, and $29 \%$ in spring. At the lower Grande Ronde River trap, 1,544 juvenile chinook salmon were captured as they left the Grande Ronde Valley from 23 October 1997 through 16 June 1998. The catch was expanded to an estimate of 8,859 migrants. Approximately $99 \%$ of the migrant population left the Grande Ronde Valley in spring. At the Lostine River trap, 5,422 juvenile chinook salmon were captured from 22 July 1997 through 30 April 1998. The catch was expanded to an estimate of 15,738 migrants. Approximately 3\% of the migrant population left upper rearing areas in Lostine River during summer, $61 \%$ in fall, $2 \%$ in winter, and 34\% in spring. At the Wallowa River trap, 4,650 juvenile spring chinook salmon were captured as they left the Wallowa Valley from 8 September 1997 through 30 April 1998. The catch was expanded to an estimate of 22,754 migrants. Approximately 55\% of the migrant population left the Wallowa Valley in fall, 5\% in winter, and $40 \%$ in spring.

Passive integrated transponders (PIT tags) were used to individually mark fish captured in traps and make subsequent observations without sacrificing the fish. Juvenile chinook salmon PIT-tagged on the upper Grande Ronde River were detected at Lower Granite Dam from 4 April to 26 June 1998, with a median passage date of 1 May. Cumulative mainstem dam detection rates for the different tag groups ranged from 10.5 to $46.8 \%$. Fish tagged during spring were detected at the highest rate. The detection rate of fish that were tagged as they left the upper rearing area in fall and that overwintered in areas downstream $(25.3 \%)$ was twice that of fish tagged during winter in upper rearing areas (10.5\%). PIT-tagged salmon from Catherine Creek were detected at Lower Granite Dam from 3 April to 26 June 1998, with a median passage date of 8 May. Cumulative mainstem dam detection rates for the different tag groups ranged from 19.4 to $45.9 \%$. Fish tagged during spring were detected at the highest rate. Juvenile salmon tagged as they left the upper rearing area in fall and overwintered in areas downstream were detected at $19.4 \%$, a similar rate as fish tagged during winter in the upper rearing area at $23.1 \%$. Lostine River fish were detected at Lower Granite Dam from 31 March through 26 May 1998, with a median passage date of 28 April. Cumulative mainstem dam detection rates for the different tag groups ranged from 38.6 to $70.4 \%$, with fish tagged during spring detected at the highest rate. Fish tagged as they left the upper rearing area in fall and that overwintered in areas downstream were detected at a higher rate than fish tagged during winter in upper rearing areas, $38.6 \%$ and $30.9 \%$, respectively.

Chinook salmon parr were generally associated with low velocity habitat types during both winter and summer habitat surveys. Parr were found in the greatest abundance in alcoves (25-27 rkm and 35-51 rkm) during winter habitat surveys in Catherine Creek and in backwater pools (0-23 rkm) in the Lostine River. During summer habitat surveys in the Lostine River, parr were most abundant in backwater and dammed pools and were observed rearing from Turkey Flat Campground to Williamson Campground (rkm 39-30) and from the Pole Bridge Picnic Area to the mouth (23-0 rkm). 
In summer 1997, we PIT-tagged parr on Catherine Creek and the Minam and Imnaha rivers in order to monitor their subsequent migration as smolts through the Snake and Columbia River hydrosystem. We found significant differences among populations in smolt migration timing at Lower Granite Dam in 1998. Fish from Catherine Creek and the Minam and Imnaha rivers were detected in the hydrosystem at rates of $16.4,20.5$, and $28.1 \%$, respectively. No parr PIT-tagged on Catherine Creek and the Imnaha, Lostine, Minam, and Wenaha rivers in 1996 (as part of the Fish Passage Center's Smolt Monitoring Program) were detected in the hydrosystem in 1998, as age $2+$ smolts.

In 1998, we estimated parr abundance and the number of parr produced per redd in Catherine Creek and the Lostine River. We estimated that 429 mature, age 1+ male parr and 13,222 immature, age 0+ parr were present in Catherine Creek in August. An average of 29 mature, age 1+ male parr and 287 immature, age 0+ parr were produced from each redd constructed in 1996 and 1997, respectively. We estimated that 75 mature, age 1+ male parr and 40,748 immature, age 0+ parr were present in the Lostine River in August. An average of 3 mature, age 1+ male parr and 832 immature, age $0+$ parr were produced from each redd constructed in 1996 and 1997, respectively. For every anadromous female spawner in Catherine Creek and the Lostine River in 1998, there were an estimated 13 and 3 mature male parr, respectively.

\section{Management Implications and Recommendations}

The Grande Ronde River Valley provides more than a migration corridor for juvenile chinook salmon. Although the proportion varies annually, large numbers of juveniles leave upper rearing areas in Catherine Creek and the upper Grande Ronde River in fall and overwinter in the Grande Ronde River Valley. Rearing habitat in the Grande Ronde Valley is significantly altered and degraded. Three years of data for the upper Grande Ronde population indicate salmon that overwinter in the valley survive at a higher rate than salmon that overwinter in upper rearing areas. Enhancing habitat conditions to improve overwinter survival in the Grande Ronde River Valley should be given priority.

Juvenile chinook salmon that leave upper rearing areas in Catherine Creek and the upper Grande Ronde and Lostine rivers during fall overwinter in lower river reaches and arrive at Lower Granite Dam earlier in spring than juveniles that overwinter in upper rearing areas. As environmental conditions in the Snake and Columbia rivers vary throughout the smolt migration, survival may vary among fish exhibiting the different life histories. In general, fall-migrating salmon have been detected at mainstem dams at rates similar to or higher than those for salmon that overwinter in upper rearing areas. However, in some years detection rates for salmon that overwinter in upper areas have been greater for an individual population. These differences point out the need to maintain the diversity of life history strategies observed in the Grande Ronde River Basin. What may be a successful strategy one year may not be as successful in another year under different conditions.

Juvenile chinook salmon use the lower reaches of non-natal tributaries in addition to the spawning streams for rearing both in the upper Grande Ronde River and Catherine Creek. These 
non-natal tributaries as well as spawning streams should be protected and enhanced. Juvenile chinook salmon are more abundant in pools than glides or riffles during both summer and winter. Maintenance of existing pool habitat and increasing habitat diversity should be a component of habitat management for chinook salmon populations in northeast Oregon streams.

The differences that exist between local populations and life history types in migration timing at Lower Granite Dam demonstrate the need to manage the hydrosystem so as to maximize survival throughout the entire migratory period of Snake River spring/summer chinook salmon smolts. Maintenance of the remaining populations in the Grande Ronde River and Imnaha River basins, their specific life histories, and any unique genetic resources they possess is critical to the continued persistence of chinook salmon in northeast Oregon and elsewhere in the Snake River Basin.

The mature male parr-to-anadromous female spawner ratios we observed in Catherine Creek and the Lostine River indicate mature male parr may have made significant gametic contributions to these populations, as has been demonstrated for Atlantic salmon. Given the continual low abundance of adult spawners, mature male parr may be an important means by which breeding population size is increased. 


\section{INTRODUCTION}

The Grande Ronde River originates in the Blue Mountains of northeast Oregon and flows $334 \mathrm{~km}$ to its confluence with the Snake River near Rogersburg, Washington. Historically, the Grande Ronde River Basin produced an abundance of salmonids including spring, summer and fall chinook salmon, sockeye salmon, coho salmon, and summer steelhead (ODFW 1990). During the past century, numerous factors have led to a reduction in salmonid stocks such that the only viable populations remaining are spring chinook salmon and summer steelhead. In addition, spring chinook salmon populations in the Grande Ronde River Basin have diminished in size and are substantially depressed from historic levels. It is estimated that prior to the construction of the Snake and Columbia river dams, more than 20,000 adult spring chinook salmon returned to spawn in the Grande Ronde River Basin annually (ODFW 1990). A spawning escapement of 12,200 adults was estimated for the basin in 1957 (USACE 1975). Recent population estimates vary from year to year, but remain at least an order of magnitude lower than historic estimates. In 1998, estimated escapement for the basin was 759 adults (253 redds x 3.0 adults/redd). The range of spring chinook salmon spawning in the Grande Ronde River Basin also has been constricted. Historically, spring chinook salmon were distributed among 21 streams, yet today most production is limited to only six tributaries, including the upper Grande Ronde River, Catherine Creek, Lookingglass Creek, the Minam River, the Lostine River and the Wenaha River (ODFW 1990).

Numerous factors are thought to have contributed to the decline of spring chinook salmon in the Snake River and its tributaries. These factors include juvenile and adult passage problems at mainstem Snake and Columbia river dams, cyclic changes in ocean productivity, overharvest, and habitat degradation associated with timber, agricultural, and land development practices. More than $80 \%$ of anadromous fish habitat in the upper Grande Ronde River is considered to be degraded (USFS 1992). Habitat problems throughout the Grande Ronde River Basin (reviewed by Bryson 1993) include poor water quality associated with high sedimentation and poor thermal buffering, moderately to severely degraded riparian zones and a decline in abundance of large pool habitat.

Precipitous declines in Snake River spring chinook salmon populations resulted in these stocks, including Grande Ronde River stocks, being listed as threatened under the Endangered Species Act (October 1992). Development of sound recovery strategies for these salmon stocks requires knowledge of stock-specific life history strategies and critical habitats for spawning, rearing, and downstream migration (Snake River Recovery Team 1993; NWPPC 1992; ODFW 1990). In addition, knowledge of juvenile migration patterns, smolt production and survival, and juvenile winter rearing habitat is needed within the basin. We currently are expanding our efforts to include life stage specific survival estimates (egg-to-parr, parr-to-smolt, and smolt-toadult), and an evaluation of the importance and frequency at which alternative life history tactics are utilized by spring chinook salmon populations in northeast Oregon.

Both historic and recent estimates of juvenile production in the basin are lacking. However, given the dramatic decline in adult returns to the basin and the extent of habitat degradation, it is reasonable to assume that juvenile production is lower now than in the past. Recent parr-to-smolt survival estimates for populations in the Grande Ronde River Basin range 
from $8.9 \%$ to $22.1 \%$ (Walters et al. 1993, 1994; Sankovich et al. 1995). These estimates are based on data from parr that were individually tagged with passive integrated transponder (PIT) tags in late summer and were detected at mainstem Snake and Columbia river dams. Before this study was initiated, it was not clear how much mortality occurred during the smolt migration and how much occurred during fall and winter rearing.

The chinook salmon smolt migration occurs in the spring. Data from Lookingglass Creek (Burck 1993), Catherine Creek (Keefe et al. 1995), the Grande Ronde River (Keefe et al. 1994, 1995), and the Lostine River (Jonasson et al. 1996, 1997) indicate an abundance of juveniles move out of upper rearing areas during the fall and overwinter downstream. Success of fall migrants varies from year to year and among streams. Over the past several years, we have estimated that 1 to $98 \%$ of the juvenile chinook salmon emigrating from upper rearing areas in streams in the Grande Ronde River Basin did so in the fall; at least 15 to $28 \%$ of the fall migrants have survived to Lower Granite Dam in the spring. We will continue to monitor the extent of the fall migrations and assess their importance to local populations.

Most juveniles that leave upper rearing areas in Catherine Creek and the upper Grande Ronde River in the fall overwinter in the Grande Ronde River Valley. Much of the habitat in these mid-reaches of the Grande Ronde River is degraded. Stream conditions in the Grande Ronde River below La Grande consist of both meandering and channeled sections of stream which run through agricultural land. Riparian vegetation in this area is sparse and provides little shade or instream cover. The river is heavily silted due to extensive erosion associated with agricultural and forest management practices and mining activities. It is reasonable to suggest that salmon overwintering in degraded habitat may be subject to increased mortality due to the limited ability of the habitat to buffer against environmental extremes. The fall migration from upper rearing areas in Catherine Creek constitutes a substantial portion of the juvenile production (Keefe et al. 1995, Jonasson et al. 1996, 1997). Therefore winter rearing habitat quantity and quality in the Grande Ronde valley may be important factors limiting chinook salmon smolt production in the Grande Ronde River.

Numerous enhancement activities have been undertaken in an effort to recover spring chinook salmon populations in the Grande Ronde River Basin. Supplementation programs have been initiated by the Oregon Department of Fish and Wildlife, the Confederated Tribes of the Umatilla Indian Reservation and the Nez Perce Tribe using endemic broodstock from the upper Grande Ronde River, Catherine Creek, and Lostine River. Information we collect will serve as the foundation for assessing the effectiveness of programs currently underway.

\section{GOALS AND OBJECTIVES}

This study was designed to document and describe early life history strategies exhibited by spring chinook salmon in the Grande Ronde River Basin. In addition to our investigations into the in-basin migration timing and abundance of juvenile chinook salmon and their seasonal habitat preference, during the past year we initiated work on life-stage-specific survival estimates and the significance of alternative early life histories. The objectives of this study were to: 1) document the annual in-basin migration patterns, including abundance, timing, and duration, of 
juvenile spring chinook salmon in the upper Grande Ronde River, Catherine Creek and the Lostine River, 2) estimate and compare survival indices from tagging to smolt detection at mainstem Snake and Columbia River dams for juveniles that leave upper river rearing areas at different times of the year, 3) determine summer and winter habitat utilization and preference of juvenile spring chinook salmon in the upper Grande Ronde River, Catherine Creek, and the Lostine River, 4) estimate and compare smolt detection rates at mainstem Columbia and Snake River dams for migrants from several local, natural populations in the Grande Ronde River and Imnaha River basins, 5) document the annual migration patterns for spring chinook salmon juveniles from several local, natural populations in the Grande Ronde River and Imnaha River basins, 6) determine survival to parr stage for spring chinook salmon in two local, natural populations in the Grande Ronde River Basin, and 7) investigate the significance of alternate life history strategies (precocious maturation in males and seaward migration at age 2+) of spring chinook salmon in two local, natural populations in the Grande Ronde River Basin.

\section{METHODS}

In this report, we assume all juvenile chinook salmon captured in traps were downstream "migrants". The term "migration year" (MY) refers to the earliest calendar year juveniles were expected to migrate to the ocean. The term "brood year" (BY) refers to the calendar year eggs were fertilized. All chinook salmon referred to in this report were naturally produced.

\section{Egg-to-Parr Survival, Abundance, and Age Composition of Parr in Summer}

Our approach to spring chinook salmon parr investigations during the 1998 summer field season was, first, to conduct parr distribution surveys on Catherine Creek and the Lostine River in July. We then conducted mark-and-recapture experiments in August to estimate the abundance of mature and immature parr in those streams. During these experiments, we collected scale samples from parr to determine age composition of the juvenile population.

We surveyed Catherine Creek and the Lostine River before conducting mark-andrecapture experiments in order to determine the rearing distribution of parr and to estimate the proportion of parr present in different reaches of each stream. Mark-and-recapture methodology requires either that marked fish mix randomly with unmarked fish, or that fish are captured in proportion to their abundance during subsequent sampling (Ricker 1975). Using knowledge of parr distribution, we attempted to capture parr in proportion to their abundance during the recapture phase of the experiments.

Distribution surveys on Catherine Creek and the Lostine River were conducted by snorkeling a systematic sample of $25 \mathrm{~m}$ transects. Surveys began upstream from the upper-most chinook salmon redd observed in 1997 and ended at trap sites located near the bottom of chinook salmon rearing habitat. We snorkeled one transect for every $100 \mathrm{~m}$ of stream within the survey area in Catherine Creek. In the Lostine River, we snorkeled one transect for every $200 \mathrm{~m}$ of stream in the upper $3 / 4$ of the survey area and one transect for every $300 \mathrm{~m}$ of stream in the lower 1/4 of the survey area. Transects were snorkeled in an upstream direction. Single pass 
counts of mature and immature chinook salmon parr were made by two or three divers, depending on stream width and visibility. Mature parr were identified based on body morphology and coloration. Mature parr are typically longer, deeper bodied, and more yellowish in color than immature parr. Stream widths were measured at the beginning, middle, and end of each transect, after fish were counted. Each survey was conducted over an $11 \mathrm{~d}$ period in July.

Following the distribution surveys, we partitioned Catherine Creek into five sections ranging in length from 2.2 to 5.7 river kilometers (rkm) and the Lostine River into six sections ranging in length from 4.8 to $9.6 \mathrm{rkm}$. Sections were selected based on parr densities and the presence of recognizable boundaries. To estimate the abundance of parr in each section, we first determined the number of parr per square meter in each transect. Transect area was calculated as the product of the length of the transect and the average of the three width measurements taken within it. Once parr densities had been determined, we calculated the area of each section as the product of its length and the average of all stream widths measured within it. We multiplied the area of each section by the average density of parr in the transect to estimate the number of parr in each section. Abundance estimates for all sections were summed to obtain total abundance estimates within the two survey areas. We then calculated the proportion of parr observed in each section. These proportions were multiplied by our numeric goals for marking and subsequent sampling (see below) to determine the number of parr to be marked and sampled in each section. This procedure was followed for immature parr only. Results from the distribution surveys demonstrated that mature parr densities were low enough to require us to mark and sample as many mature parr as we could capture, regardless of their location. Although we were able to obtain abundance estimates from the distribution survey data, we assumed these estimates were negatively biased and less accurate than estimates obtained using mark-and-recapture techniques (Rodgers et al. 1992).

We began our mark-and-recapture experiments immediately following the distribution surveys. We captured, marked, and released parr during the first week in August on Catherine Creek and the second week in August on the Lostine River. We conducted subsequent sampling during the third week in August on Catherine Creek and the fourth week in August on the Lostine River. Our goal on each stream was to mark 1,000 immature parr and as many mature parr as we could capture in $5 \mathrm{~d}$ (not to exceed 1,000). During subsequent sampling, our goal was to capture 500 immature parr and as many mature parr as possible in $5 \mathrm{~d}$ (not to exceed 500).

Parr were located by snorkelers and captured by beach seining or herding fish into seines set perpendicular to the stream flow. Captured fish were held in aerated 19 L buckets or in $19 \mathrm{~L}$ carboys attached to pack frames. Fish were transferred periodically to live cages anchored in shaded areas of the stream. Daily collections continued until we captured a sufficient number of parr to mark or until stream temperatures reached $17^{\circ} \mathrm{C}$.

Prior to being marked, fish were anesthetized in an aerated bath containing 40 to $50 \mathrm{mg} / \mathrm{L}$ of tricaine methanesulfonate (MS-222). We sorted fish in the bath to remove any that were injured or in poor condition. We marked all mature parr, and any immature parr less than $55 \mathrm{~mm}$ fork length, with Alcian Blue dye (applied with a tattoo machine above the anal fin). Immature parr greater than or equal to $55 \mathrm{~mm}$ fork length were either PIT-tagged or dye-marked. PIT tags were injected manually with modified hypodermic syringes as described by Prentice et al. (1986, 
1990) and Mathews et al. $(1990,1992)$. Syringes were disinfected for 10 min in $70 \%$ isopropyl alcohol between each use. We used a portable tagging station that consisted of a computer, PIT tag reader, measuring board, and electronic balance to record the tag code, fork length (FL, 1 $\mathrm{mm})$, and weight $(0.1 \mathrm{~g})$ of PIT-tagged fish. We recorded the length and weight of all but a small portion of the mature parr and the length of immature parr that were dye-marked. We collected scale samples from all mature parr captured and from a haphazard sample of 200 immature parr. We continued to process fish only as long as stream temperatures remained at or below $15^{\circ} \mathrm{C}$. On some occasions, it was necessary to hold fish overnight and resume marking the following morning. All fish were released on the day they were processed, in the area of capture. We made releases in 22 different areas covering $22 \mathrm{~km}$ of stream on Catherine Creek, and 20 different areas covering $41 \mathrm{~km}$ of stream on the Lostine River. In order to facilitate the dispersal of fish, we scattered small groups over several riffles within each area.

During subsequent sampling, we captured fish throughout each stream section. We inspected each fish for marks and maturity status and recorded the number of mature and immature parr that were unmarked, dye-marked, PIT-tagged, or that had a tagging scar but lost their PIT tag. Scale samples were collected from unmarked, mature parr to augment the samples taken during marking.

The abundance of immature and mature parr in Catherine Creek and the Lostine River was determined using an adjusted Petersen estimate (Ricker 1975). Ninety-five percent confidence intervals were obtained using values in Appendix II and equation (3.7) in Ricker (1975). Age compositions of immature and mature parr were based on results from scale analysis. Scale impressions were made on acetate slides and inspected on a microfiche reader at $42 x$ magnification. We counted annuli to determine whether parr were age $0+$ (no annulus) or $1+$ (one annulus). We calculated the proportion of immature and mature parr at each age and obtained 95\% confidence intervals from Table P in Rohlf and Sokal (1995).

Using information gathered from the mark-and-recapture experiments, scale analyses, spawning surveys, and a previous year of this study, we determined the following: 1) the abundance of immature and mature parr, by age class, in Catherine Creek and the Lostine River in August 1998 and 2) the percentage of immature parr present in Catherine Creek in August 1997 that matured and were present in Catherine Creek in August 1998. To calculate the percentage of maturing parr, we first had to estimate the abundance of immature parr in August of 1997. We did so using the adjusted Peterson estimate (Ricker 1975) and trapping data for unmarked juveniles and juveniles PIT-tagged as parr in 1997 (Jonasson et al. 1997). We could not make a similar calculation for salmon in the Lostine River, because no parr were PIT-tagged there in 1997. An additional objective of our parr investigation was to estimate egg-to-parr survival rates for populations in Catherine Creek and the Lostine River. Because information on the fecundity of female chinook salmon in these streams is lacking, we were not able to make these estimates this year. Instead we developed an estimate of parr per redd as a means of tracking parr production. The numbers of age $0+(1997$ brood) and age 1+ (1996 brood) parr produced per redd were calculated using summer parr abundance, age composition, and 1996 and 1997 redd estimates for the Catherine Creek and Lostine River populations. We anticipate the ODFW's Endemic Brood Project will begin collecting fecundity data in the near future. 


\section{In-Basin Migration Timing and Abundance}

The seasonal migration timing and abundance of juvenile spring chinook salmon in the upper Grande Ronde River, Catherine Creek and the Lostine River were determined by operating rotary screw traps year round. In the Grande Ronde River subbasin, one rotary screw trap was located below spawning and upper rearing areas in the upper Grande Ronde River near the town of Starkey at rkm 299 (Figure 1). A second trap was located in Catherine Creek below spawning and upper rearing areas near the town of Union at rkm 32. Catherine Creek enters the Grande Ronde River at rkm 225 and is a major tributary for spring chinook salmon spawning and rearing. A third rotary screw trap was located in the Grande Ronde River at the lower end of the Grande Ronde Valley near the town of Elgin at rkm 164. At our upper Grande Ronde River trap site, a 1.5 m diameter trap was fished from 1 July 1997 through 30 June 1998. A 1.5 m diameter trap was fished at the Catherine Creek site from 23 July 1997 through 30 June 1998. At our lower Grande Ronde River trap site, a 1.5 m diameter trap was fished from 29 September 1997 through 18 February 1998. We fished a $2.4 \mathrm{~m}$ diameter trap at this site from 19 February 1998 through 30 June 1998.

In the Wallowa River subbasin, one rotary screw trap was located below the majority of spawning and rearing areas on the Lostine River near the town of Lostine at rkm 3 (Figure 1). A $1.5 \mathrm{~m}$ diameter trap was fished at this site from 1 September 1997 through 30 April 1998. A second rotary screw trap was located on the Wallowa River above the mouth of the Minam River near the town of Wallowa at rkm 27 (Figure 1). This trap was located below spawning and rearing areas of Hurricane, Prairie, Bear, and Parsnip creeks, the upper Wallowa River and the Lostine River. A 2.4 m diameter trap was fished at this site from 8 September 1997 through 30 April 1998.

The rotary screw traps were equipped with live boxes that safely held hundreds of juvenile spring chinook salmon trapped over 24 to $72 \mathrm{~h}$ periods. The traps were generally checked daily, but were checked as infrequently as every third day when only a few fish were captured per day and environmental conditions were not severe. All juvenile spring chinook salmon captured in traps were removed for enumeration and interrogated for PIT tags. We attempted to measure fork lengths ( $\mathrm{mm}$ ) and weights $(\mathrm{g})$ of at least 100 juvenile spring chinook salmon each week. Prior to sampling, juvenile spring chinook salmon were anesthetized with MS-222 (40-60 mg/L). Fish were allowed to recover fully from anesthesia before release into the river. River height was recorded daily from permanent staff gauges. Water temperatures were recorded daily at each trap location using thermographs or hand held thermometers.

Migrant abundance was estimated by conducting trap efficiency tests throughout each trapping season at each trap site. Trap seasons were defined from catch distributions. Trap efficiency was determined by releasing a known number of paint-marked or PIT-tagged fish above each trap and enumerating recaptures. A Panjet marking instrument (Hart and Pitcher 1969) was used to paint-mark fish by injecting a small amount of non-toxic acrylic paint subcutaneously. Up to 100 juvenile spring chinook salmon were marked and released each week. On days when a trap stopped operating and no marked fish were recaptured, the number of marked fish released the previous day were subtracted from the seasonal total. 


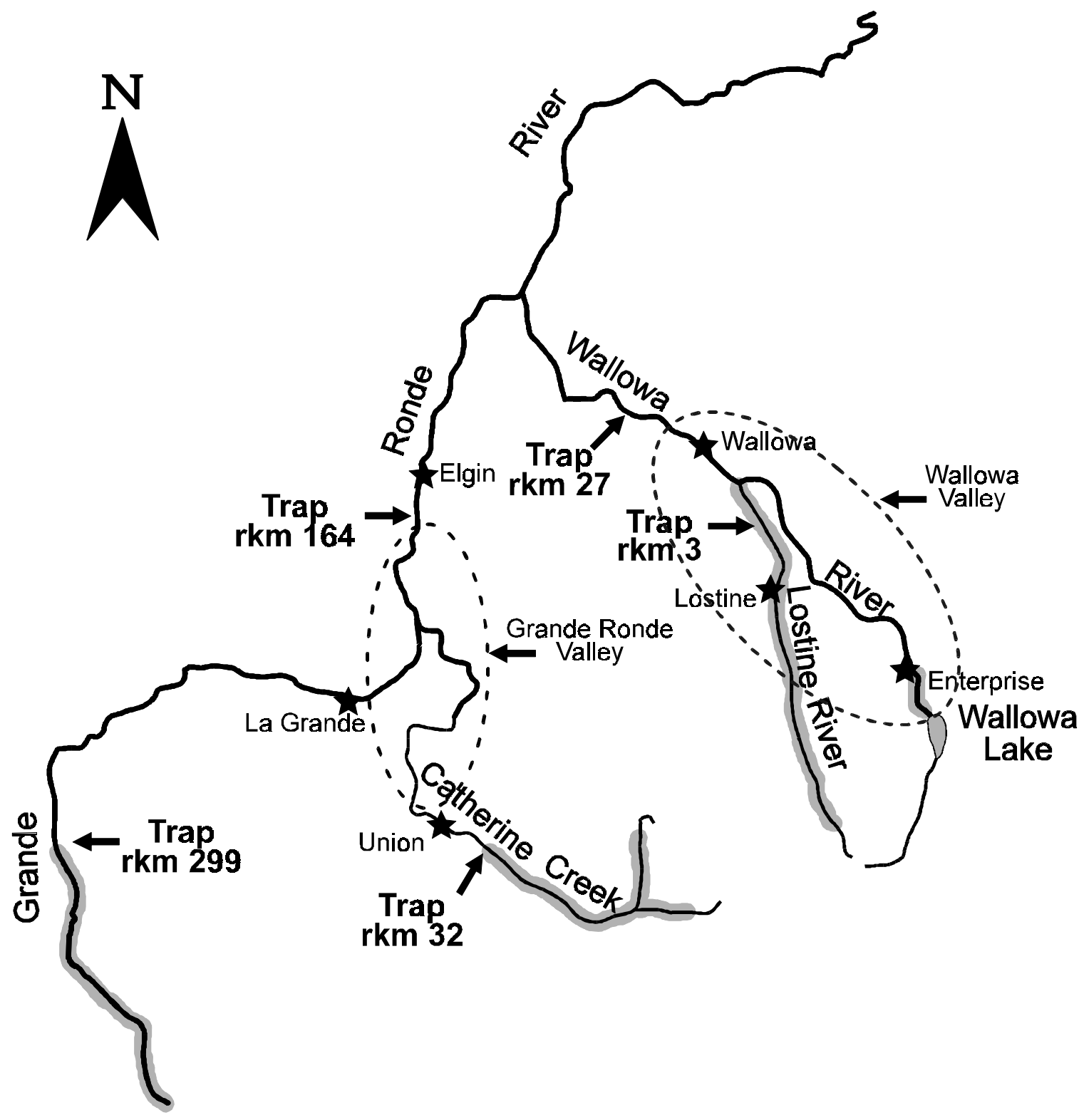

Figure 1. Locations of fish traps in the Grande Ronde River Basin during the study period. Shaded areas delineate spring chinook salmon spawning and upper rearing areas in each study stream. Dashed lines indicate the Grande Ronde River and Wallowa River valleys. 
Trap efficiency was estimated by

$$
\hat{E}=R / M ;
$$

where $\hat{E}$ is the estimated seasonal trap efficiency, $M$ is the number of marked fish released upstream, and $R$ is the number of marked fish recaptured.

The abundance of migrants that passed each trap site for each trapping season (summer, fall, winter, and spring) was estimated by

$$
\hat{N}=U / \hat{E} ;
$$

where $\hat{N}$ is the estimated number of fish migrating past the trap, $U$ is the total number of unmarked fish captured, and $\hat{E}$ is the estimated seasonal trap efficiency.

Variance for each $\hat{N}$ was estimated by the one-sample bootstrap method (Efron and Tibshirani 1986; Thedinga et al. 1994) with 1,000 iterations. Each bootstrap iteration calculated $\hat{N}$ from equations (1 and 2) drawing $R$ and $U$ from the binomial distribution. Confidence intervals for $\hat{N}$ were calculated by

$$
95 \% C I=1.96 \sqrt{V} ;
$$

where $V$ is the estimated variance of $\hat{N}$ determined from the bootstrap. Abundance for the total migration past each trap was determined by adding the seasonal estimates. Seasonal variance estimates were summed to obtain estimated variance for the total migration. Migrant fry were able to escape from the trap without detection and, therefore, were not included in migrant abundance estimates. Sexually mature male parr were not included in migrant abundance estimates.

The lower Grande Ronde River trap and the Wallowa River trap were located below hatchery steelhead release sites. It was necessary to monitor these two traps continuously throughout the hatchery steelhead release periods to prevent overcrowding in trap live boxes. A portable fish sorter was designed to separate juvenile spring chinook salmon from larger steelhead migrants. Larger steelhead slid off the sorter directly back into the river. Juvenile spring chinook salmon migrants passed through the sorter into a live well. All fish were netted directly from the trap live box to a fish sorter to minimize handling during release periods.

Hatchery steelhead releases into the Wallowa River during the spring season necessitated modifications to our method of estimating migrant abundance at the Wallowa trap. During low catch periods, the trap was fished continuously throughout a $24 \mathrm{~h}$ period. During high catch periods, the trap was fished systematically (each night) for a $4 \mathrm{~h}$ interval from 20:00 to 24:00 using systematic two-stage sampling. Systematic sampling allowed us to reduce fish handling and overcrowding in the live box, and avoid labor intensive $24 \mathrm{~h}$ trap monitoring. Preliminary $24 \mathrm{~h}$ sampling indicated a strong diel pattern in chinook salmon catch rates. The interval from 20:00 to 24:00 was chosen because a relatively large proportion of the total daily catch was captured during this $4 \mathrm{~h}$ time block (Figure 2). Trap efficiency tests were conducted throughout the spring period whenever we were able to fish the trap continuously. Marked recaptures captured during the systematic sampling interval (20:00 to 24:00) were not included in seasonal totals. 
Systematic sampling required us to estimate the proportion of the total daily catch captured during our sampling interval, i.e., during the systematic sampling interval from 20:00 to 24:00 or continuous sampling interval from 08:00 to 08:00 (24 h). We estimated the proportion of the total daily catch captured during the sampling interval by fishing the trap over six $24 \mathrm{~h}$ periods through the spring migration period and counting the number of fish trapped during the six successive $4 \mathrm{~h}$ intervals within each $24 \mathrm{~h}$ period. The proportion of the total daily catch captured during the sampling interval $(i)$ was estimated by

$$
\hat{P}_{i}=S_{i} / C
$$

were $\hat{P}_{i}$ is the estimated proportion of the total daily catch for sampling interval $i, S_{i}$ is the total number of fish caught during sampling interval $i$ throughout the six $24 \mathrm{~h}$ sampling periods, and $C$ is the total number of fish caught throughout the six $24 \mathrm{~h}$ sampling periods.

Abundance during the spring period at the Wallowa trap was estimated for systematic and continuous sampling intervals by

$$
\hat{N}_{s}=\left(U_{i} / \hat{P}_{i}\right) / \hat{E} ;
$$

where $\hat{N}_{s}$ is the estimated number of fish migrating past the trap and $U_{i}$ is the total number of unmarked fish captured during interval $i$. Abundance for the total spring migration at the Wallowa trap was determined by summing the continuous and systematic sampling estimates.

Variance for $\hat{N}_{s}$ at the Wallowa trap during spring was estimated by the one-sample bootstrap method (Efron and Tibshirani 1986; Thedinga et al. 1994) with 1,000 iterations. Each bootstrap iteration calculated $\hat{N}_{s}$ from equations (1, 4, and 5) drawing $R$ and $S_{i}$ from the binomial distribution and $U_{i}$ from the Poisson distribution. Confidence intervals for the spring period were calculated using equation (3) where $V$ is the estimated variance of $\hat{N}$ (continuous + systematic) determined from the bootstrap.

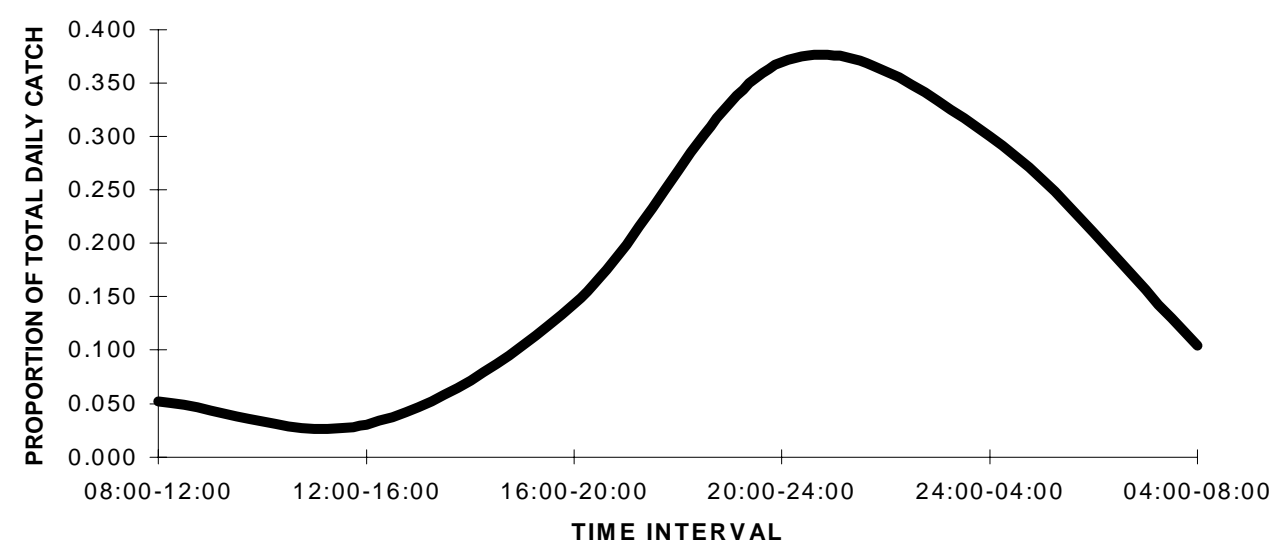

Figure 2. Diel pattern observed in capture of juvenile spring chinook salmon at the Wallowa trap during spring. Capture rates were determined from six $24 \mathrm{~h}$ sampling periods in which 230 fish were captured. 


\section{Migration Timing and Survival to Lower Granite Dam}

\section{Juvenile Trapping Studies}

PIT tag technology allows fish to be individually marked and subsequently observed without being sacrificed. First-time detections of PIT-tagged fish at Snake and Columbia river dams were used to estimate migration timing and index survival among tag groups. During the 1998 migration year, PIT tag interrogation systems were used in juvenile bypass systems at six of eight Snake River and Columbia River dams to monitor fish passage.

Fish that emigrate from upper rearing areas at different times of the year and overwinter in different habitats are subject to different environmental conditions. Survival may vary among fish exhibiting the different life histories as a result. There is a distinct fall migration from summer rearing areas in the upper Grande Ronde River, Catherine Creek, and the Lostine River to areas downstream where fish overwinter. These fall migrants then migrate out of the basin to the sea the following spring. Other individuals remain in upper rearing areas through the fall and winter, and initiate their seaward migration in the spring. To determine if there were differences within populations with respect to the survival of juveniles that overwintered in different locations, we planned to tag 500 spring chinook salmon migrants captured in traps during the fall and spring and 500 spring chinook salmon that were residing above the traps in the winter. For tagging purposes and to be consistent with previous years of this study, we defined the fall migration as downstream movement past our upper trap sites between September and December and the spring migration as downstream movement past our upper trap sites between February and May. These times encompassed a majority of the fall and spring migrations. We also tagged 500 to 1,000 chinook salmon parr on Catherine Creek, and the Imnaha and Minam rivers in late summer 1997 as part of our investigation into parr strategies (Objectives 4-7).

Thus, there are four tag groups used to estimate migration timing and index survival to Lower Granite Dam: summer, fall, winter, and spring. Fish tagged in these groups do not necessarily represent unique life history strategies. For example, the summer tag group includes fish that migrate out of upper rearing areas in the fall, winter, or spring, and overwinter in either the upper or lower rearing areas. The summer tag group includes fish that exhibit all possible life histories and, as such, depicts timing and survival for the overall population. PIT-tagged fish were interrogated upon recapture in screw traps and in bypass systems at mainstem dams. All recaptured and interrogated fish were identified by their original tag group, thereby insuring the independence of tag groups for analysis. For example, dam detections of fish that were tagged in the summer and were recaptured at a river trap in the fall, were analyzed as summer tagged fish.

We estimated migration timing of individual tag groups at Lower Granite Dam by expanding daily numbers of PIT tag detections according to the proportion of river flow spilled each day. This procedure was necessary because some fish may pass undetected over the spillway and the amount of spill varies throughout the migration season. We assumed the proportion of fish that passed over the spillway (spill effectiveness) was directly related to the proportion of flow spilled. This assumption conforms fairly well to data obtained using nonspecies-specific hydroacoustic methods (Kuehl 1986). Kuehl (1986) estimated spill effectiveness at 11,19, and $35 \%$ under 4,20 , and $40 \%$ spill conditions, respectively. We also 
assumed there was no temporal variation either in the proportion of fish diverted from turbine intakes into the bypass system (fish guidance efficiency) or in the proportion of fish that passed through the surface bypass collector. We made these assumptions in light of evidence to the contrary (Giorgi et al. 1988, Swan et al. 1986, Johnson et al. 1997) because the data required to account for such variation were unavailable. The extent to which our results may be biased would depend on the overall rates of fish passage via the bypass system and surface bypass collector, and on the degree to which daily rates of fish passage by these routes may have varied throughout the migration seasons. The number of fish migrating past Lower Granite Dam by week was calculated by multiplying the number of fish detected each day by a daily expansion factor, which was calculated as:

$$
\text { Expansion factor }=(\text { powerhouse flow }+ \text { spillway flow }) / \text { powerhouse flow }
$$

Daily products were added and rounded to the nearest integer.

At the completion of the 1998 migration year, we obtained cumulative first-time detection information from PIT tag interrogation sites at Lower Granite, Little Goose, Lower Monumental, McNary, John Day, and Bonneville dams. We calculated survival indices for individual tag groups by dividing the cumulative number of first-time PIT tag detections at these sites by the number of fish released in each tag group and expressed this proportion as a percentage. We did not adjust our data to compensate for tagged fish that may have passed through the hydrosystem without being detected because we are unsure of the most appropriate methods to use at the time of this report. Therefore, the survival indices may only indicate the minimum rate of survival for each tag group. We evaluated relative success of fish that leave upper rearing areas at different times of the year by comparing the survival indices of fall and winter tag groups. Overwinter survival of fish that remained in upper rearing areas was assessed by dividing the survival indices of the winter tag groups by the corresponding index for the spring tag group. This proportion was then expressed as the percentage of fish in upper rearing areas that survived the winter. The survival indices for the summer tag groups provided information about the overall population survival from the time of tagging through the following smolt migration.

\section{Parr Studies}

In 1997 and 1998, we PIT-tagged chinook salmon parr from several local populations in the Grande Ronde and Imnaha River basins in order to monitor their migration timing as smolts at Lower Granite Dam and their rates of detection in the hydrosystem. In 1997, we PIT-tagged parr on Catherine Creek and the Minam and the Imnaha rivers. We PIT-tagged parr on those streams and the Lostine River in 1998. We conducted tagging operations in late summer (Table 1) so that few fish would be too short to tag $(<55 \mathrm{~mm}$ FL). Sampling occurred primarily in areas where spawning adults were concentrated the previous year. To collect and PIT tag the parr, we used the methods outlined previously for the mark-and-recapture experiments (see Methods, Parr-to-Smolt Survival, Abundance, and Age Composition of Parr in Summer). In summer 1997, we released from 495 to 1,010 PIT-tagged parr in Catherine Creek and the Imnaha and Minam rivers (Table 1). We released from 502 to 1,009 PIT-tagged parr in those streams and the 
Lostine River in summer 1998 (Table 1). Information on the migration timing and detection rates of parr PIT-tagged in 1998 will be reported next year.

We estimated the timing with which fish from the different streams migrated through Lower Granite Dam in the same manner as described above for fish in the juvenile trapping studies. To determine if migration timing differed among populations, we performed a KruskalWallis test on the dates of detection, expressed as day of year, of real and "expanded" fish. When significant differences were found, we used a multiple-comparison procedure (at alpha=0.05; Daniel 1990) to further analyze the data. First-time detection rates of fish from the different streams were calculated in the manner outlined above for fish in the juvenile trapping studies.

Table 1. Dates of tagging and number of chinook salmon parr PIT-tagged on various northeast Oregon streams in 1997 and 1998.

\begin{tabular}{cccc}
\hline Year and stream & $\begin{array}{c}\text { Dates of collection } \\
\text { and tagging }\end{array}$ & $\begin{array}{c}\text { Number of parr } \\
\text { PIT-tagged } \\
\text { and released }\end{array}$ & $\begin{array}{c}\text { Kilometers upstream from } \\
\text { Lower Granite Dam }\end{array}$ \\
\hline 1997 & 18-22 August & 495 & $352-369$ \\
Catherine Creek & 2-3 September & 998 & $282-284$ \\
Minam River & 8-9 September & 1,010 & $237-241$ \\
Imnaha River & & & \\
1998 & 3-7 August & 502 & $354-375$ \\
Catherine Creek & 10-13 August & 506 & $274-302$ \\
Lostine River & 17-19 August & 1,006 & $280-284$ \\
Minam River & 24-26 August & 1,009 & $237-243$ \\
Imnaha River &
\end{tabular}

\section{Habitat Utilization}

We assessed habitat utilization for chinook salmon parr during the winter on the upper Grande Ronde River, Catherine Creek, and the Lostine River. Habitat utilization and rearing distribution were assessed for chinook salmon parr during the summer on the Lostine River. Fish were counted by visual observation with two or three persons snorkeling habitat units in an upstream direction. Three counts were made for each habitat unit sampled. Winter counts were made during the night with the use of dive lights, while summer observations were made during the day.

Sampling sites were selected based on redd and rearing distribution surveys from previous years, physical habitat surveys, and accessibility. We surveyed Catherine Creek during the winter from $3 \mathrm{~km}$ up both the North and South Forks down to rkm 27 and from rkm 18 to 19, above the town of Union. We surveyed the Lostine River during the winter from the Pole Bridge Picnic Area down to the mouth (rkm 23-0). During the summer, we surveyed the Lostine River 
from Turkey Flat Campground to Williamson Campground (rkm 39-30) and from Pole Bridge Picnic Area to the mouth (rkm 23-0).

We identified habitat types using the habitat classification system described in Bisson et al. (1982) and modifications for backwater pools described by Nickelson et al. (1992). Fish of all species were enumerated and the following habitat variables were recorded: habitat type, surface area, depth, cover, substrate composition, water temperature, water velocity, slope, shade, and water visibility. The mean density of chinook salmon parr per habitat type was calculated as the maximum of three fish counts divided by the surface area of each habitat unit. 


\section{RESULTS AND DISCUSSION}

\section{Egg-to-Parr Survival, Abundance, and Age Composition of Parr in Summer}

From the information obtained during our mark-and-recapture experiments, we estimated that 429 (95\% CI: 237-858) mature male parr and 13,222 (95\% CI: 10,047-17,189) immature parr were present in Catherine Creek in early-August 1998 (Table 2). All of the mature parr sampled for scales were age 1+ (BY 1996), whereas all of the immature parr were age 0+ (BY 1997)( Table 3). Based on our abundance and age composition estimates, and on redd counts from previous years, we determined that an average of 29 mature, age 1+ parr and 287 immature, age $0+$ parr were produced from each redd constructed in 1996 and 1997, respectively. Our abundance estimate for mature parr indicated further that $1.6 \%$ of the 26,608 immature parr estimated to be present in Catherine Creek in August 1997 (P. Sankovich, unpublished data) matured and were present in Catherine Creek in August 1998.

Table 2. Results from mark-and-recapture experiments conducted in Catherine Creek and the Lostine River in August 1998.

\begin{tabular}{lcccc}
\hline Stream and group & $\begin{array}{c}\text { Number } \\
\text { marked }(\mathrm{M})\end{array}$ & $\begin{array}{c}\text { Number } \\
\text { sampled }(\mathrm{C})\end{array}$ & $\begin{array}{c}\text { Number } \\
\text { Recaptured (R) }\end{array}$ & $\begin{array}{c}\text { Population estimate }(\hat{\mathrm{N}}) \\
(95 \% \mathrm{CI})\end{array}$ \\
\hline $\begin{array}{c}\text { Catherine Creek } \\
\text { Immature }\end{array}$ & 1,050 & 628 & 49 & $13,222(10,047-17,819)$ \\
Mature & 73 & 57 & 9 & $429(237-858)$ \\
Lostine River & & & & \\
$\quad$ Immature & 1,010 & 926 & 22 & $40,748(27,403-63,324)$ \\
Mature & 14 & 9 & 1 & $75(23-136)$ \\
\hline
\end{tabular}

Abundance estimates for mature and immature parr in the Lostine River in mid-August 1998 were 75 (95\% CI: 23-136) and 40,748 (95\% CI: 27,403-63,324), respectively (Table 2). The abundance estimate for mature parr may have been biased because we recaptured only one marked, mature parr (Ricker 1975) (Table 2). As in Catherine Creek, all of the mature and immature parr sampled for scales were ages $1+$ and $0+$, respectively (Table 3 ). We estimated that an average of 3 mature, age 1+ parr were produced from each redd constructed in 1996. An average of 832 immature, age 0+ parr were produced from each redd in 1997.

An interesting note regarding chinook salmon populations in Catherine Creek and the Lostine River is that there were an estimated 13 and 3 mature male parr for every anadromous female spawner (i.e., redd) in the respective streams in 1998. To our knowledge, it has not been shown whether mature chinook salmon parr are capable of fertilizing eggs and producing viable offspring, as has been demonstrated in Atlantic salmon (Thorpe and Morgan 1980; Hutchings and Myers 1985, 1988). Therefore, we can conclude only that the potential existed for mature parr to have made significant gametic contributions to their respective populations. Given the continual low abundance of anadromous spawners in northeast Oregon streams, mature male parr may be an important means by which breeding population size is increased. 
Table 3. Age composition of immature and mature chinook salmon parr sampled in Catherine Creek and the Lostine River in 1998. Age was determined by analysis of scales.

\begin{tabular}{cccc}
\hline $\begin{array}{c}\text { Stream and } \\
\text { group }\end{array}$ & $\begin{array}{c}\text { Number of } \\
\text { samples }\end{array}$ & $\begin{array}{c}\text { Percent age 0+ } \\
(95 \% \mathrm{CI})\end{array}$ & $\begin{array}{c}\text { Percent age 1+ } \\
(95 \% \mathrm{CI})\end{array}$ \\
\hline Catherine Creek & & & \\
Immature & 208 & $100.0(98.2-100.0)$ & $0.0(0.0-1.8)$ \\
Mature & 113 & $0.0(0.0-3.3)$ & $100.0(96.7-100.0)$ \\
& & & \\
Lostine River & 231 & $100.0(98.4-100.0)$ & $0.0(0.0-1.6)$ \\
Immature & 20 & $0.0(0.0-16.7)$ & $100.0(83.3-100.0)$ \\
Mature & &
\end{tabular}

\section{In-Basin Migration Timing and Abundance}

The upper Grande Ronde River trap fished for $225 \mathrm{~d}$ from 11 July through ice up on 2 December 1997, and from 6 February 1998 through 30 June 1998. Distinct fall and spring migrations were evident (Figure 3), while smaller numbers of salmon were captured during summer and winter (Table 4). The date that the median fall migrant passed the trap was 31 October and was similar to timing observed in MY 94, 95, and 96. Timing in MY 97 was somewhat later with the median fall migrant moving past our upper trap on 13 November. The date that the median spring migrant moved past the trap was 25 March and was consistent with past observations that ranged from 15 to 31 March.

We estimated a minimum of 6,716 \pm 618 juvenile spring chinook salmon migrants moved out of the upper Grande Ronde rearing areas during MY 1998. This estimate is considerably greater than our estimate of 66 fish in MY 97 and is more consistent with estimates from MY 94 through 96 that ranged from 1,151 to 30,926. Seasonal trap efficiencies were 5.3, 70.2, 27.3, and $38.4 \%$ for summer, fall, winter, and spring, respectively. Based on these efficiencies, we estimated that approximately $29 \%(1,953 \pm 132)$ of the migrants moved in fall and 63\% $(4,221 \pm$ $446)$ migrated in spring. In addition, approximately $6 \%(399 \pm 359)$ moved in summer and $2 \%$ $(142 \pm 191)$ moved during winter. At $29 \%$, the proportion of fall migrants leaving the upper Grande Ronde rearing areas was greater than the proportion observed in MY 94 (10\%) and MY $95(11 \%)$. The pattern of a dominant spring migration in the upper Grande Ronde is consistent for all migration years studied to date with the exception of MY 97, when $98 \%$ of the migrants moved in fall. It is worth mentioning, however, that MY 97 was exceptional in that only 29 fish were trapped. 


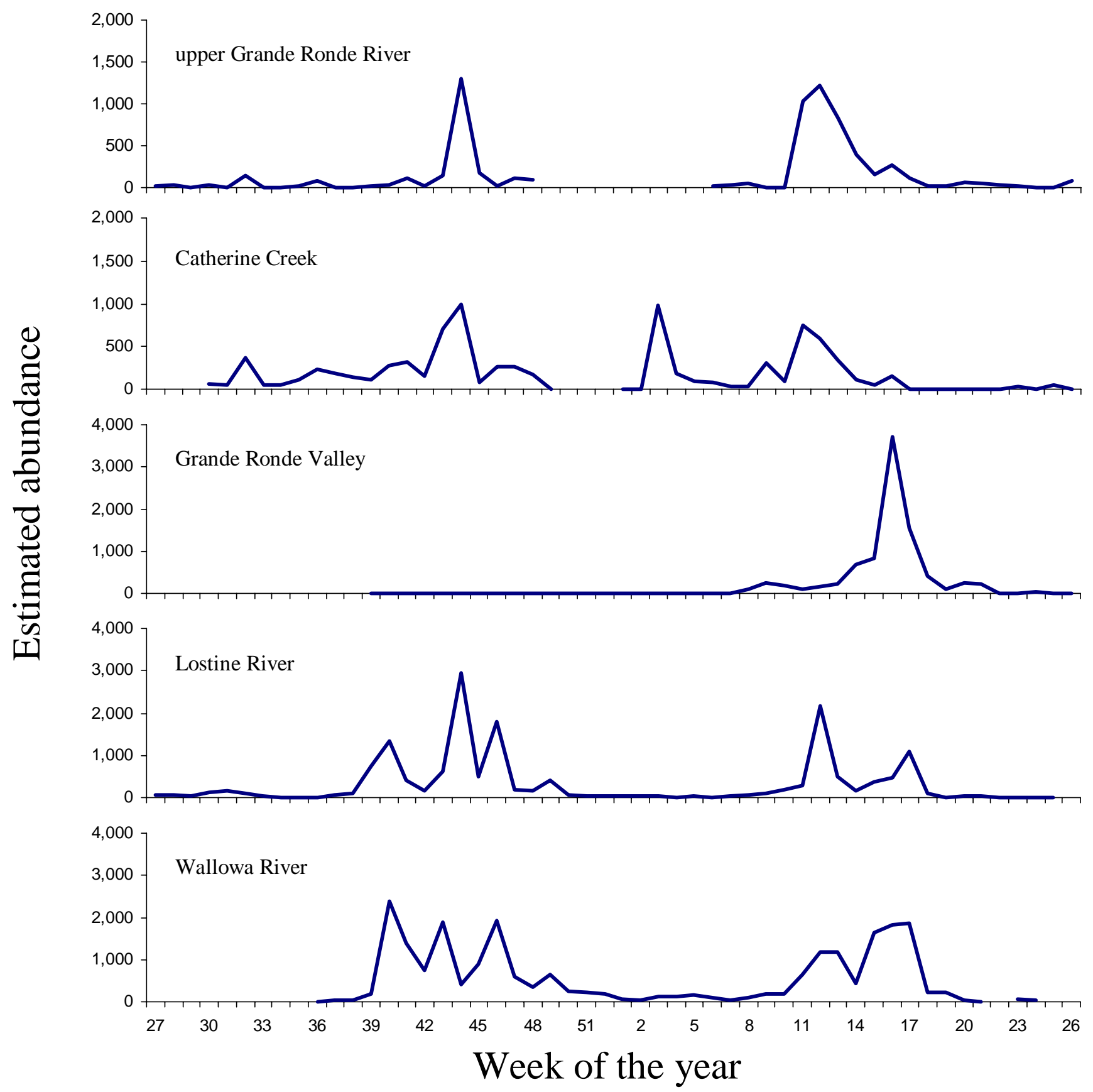

Figure 3. Estimated migration timing and abundance of juvenile spring chinook salmon migrants captured by rotary screw traps. During the 1998 migration year, traps were located at rkm 299 and 164 of the Grande Ronde River, rkm 32 of Catherine Creek, rkm 3 of the Lostine River, and rkm 27 of the Wallowa River. 
Table 4. Seasonal catch of juvenile chinook salmon at five trap locations in the Grande Ronde River Basin.

\begin{tabular}{|c|c|c|c|c|}
\hline Trap site & Season & Migration period & $\begin{array}{c}\text { Days } \\
\text { fished }\end{array}$ & $\begin{array}{l}\text { Trap } \\
\text { catch }\end{array}$ \\
\hline \multirow[t]{4}{*}{ Upper Grande Ronde } & Summer & 1 Jul 97 - 16 Sep 97 & 74 & 21 \\
\hline & Fall & 17 Sep $97-2 \operatorname{Dec} 97$ & 67 & 1,372 \\
\hline & Winter & 3 Dec $97-25$ Feb 98 & 5 & 39 \\
\hline & Spring & 26 Feb $98-30$ Jun 98 & 109 & 1,620 \\
\hline \multirow[t]{4}{*}{ Catherine Creek } & Summer & 23 Jul 97 - 16 Sep 97 & 77 & 212 \\
\hline & Fall & $17 \operatorname{Sep} 97-2 \operatorname{Dec} 97$ & 77 & 1,535 \\
\hline & Winter & 3 Dec $97-11$ Feb 98 & 32 & 587 \\
\hline & Spring & 12 Feb 98 - 30 Jun 98 & 118 & 855 \\
\hline \multirow[t]{2}{*}{ Grande Ronde Valley } & Fall & 29 Sep $97-18$ Feb 98 & 140 & 4 \\
\hline & Spring & 19 Feb 98 - 30 Jun 98 & 113 & 1,540 \\
\hline \multirow[t]{4}{*}{ Lostine River } & Summer & 22 Jul 97 - 30 Aug 97 & 65 & 88 \\
\hline & Fall & 1 Sep $97-31$ Dec 97 & 107 & 3,328 \\
\hline & Winter & 1 Jan 98 - 28 Feb 98 & 49 & 137 \\
\hline & Spring & 1 Mar 98 - 30 Apr 98 & 60 & 1,869 \\
\hline \multirow[t]{3}{*}{ Wallowa River Valley } & Fall & 8 Sep 97 - 31 Dec 97 & 104 & 2,335 \\
\hline & Winter & 1 Jan $98-11$ Mar 98 & 62 & 274 \\
\hline & Spring & $12 \operatorname{Mar} 98$ - 30 Apr 98 & 45 & 2,041 \\
\hline
\end{tabular}

The Catherine Creek trap fished for 304 d from 28 July through ice up on 5 December 1997, and from 5 January through 30 June 1998. Substantial numbers of migrants were captured continually from the time we deployed the trap in summer through spring (Figure 3). The date that the median migrant passed the trap by season was 22 August, 30 October, 21 January, and 19 March for summer, fall, winter and spring, respectively (Table 4). The pattern of continual movement out of Catherine Creek has been emerging over the past few years. With higher summer flows and warmer winter weather, we have been able to extend our trapping earlier into summer and later into winter. We do not know whether this pattern simply reflects an increase in trapping effort or is a response to interannual changes in environmental conditions in Catherine Creek. We will attempt to address this issue over the next few years. 
We estimated that a minimum of $8,763 \pm 759$ juvenile spring chinook salmon migrants moved out of the upper Catherine Creek rearing areas during MY 98. This estimate is greater than, yet on the same order of magnitude as, estimates from MY $97(3,951)$ and MY $96(6,341)$ and is considerably lower than our migrant estimate from MY $95(18,680)$. Seasonal trap efficiencies at Catherine Creek were 19.3, 46.6, 31.7 and 33.9\% for summer, fall, winter, and spring, respectively. Based on these efficiencies, we estimated that approximately 12\% (1,096 \pm $375)$ of the migrants moved in summer, $37 \%$ (3,292 \pm 271$)$ moved in fall, $21 \%(1,852 \pm 492)$ moved in winter and 29\% (2,523 \pm 346$)$ migrated in spring. The Catherine Creek population appears to be different from the upper Grande Ronde population with respect to the proportion of fish migrating in spring and fall. The proportion of spring migrants has ranged from 11 to $50 \%$ of the total migrant population while the proportion of fall migrants has ranged from 37 to $76 \%$. In contrast, the largest outmigration from the upper Grande Ronde River has consistently been observed in spring.

The lower Grande Ronde River trap fished for 253 d between 23 October 1997 and 16 June 1998. A distinct spring migration was evident; few fish passed the trap in fall and winter (Figure 3). The date that the median migrant passed the trap was 20 April and was similar to timing observed in MY 95 and 96. Timing in MY 97 was somewhat later with the median migrant moving past this trap on 8 May.

We estimated that a minimum of 8,859 $\pm 1,490$ juvenile spring chinook salmon migrants left the Grande Ronde Valley during MY 98. The magnitude of this estimate is consistent with estimates from MY 96 and 97 that were 2,475 and 9,001 migrants respectively, and is one order of magnitude lower than our estimates in MY 94 and 95. Seasonal trap efficiency was $17.4 \%$ for our $2.4 \mathrm{~m}$ trap. Only four fish were captured in fall with our $1.5 \mathrm{~m}$ trap and thus we were not able to determine trap efficiency. As in the past four years, more than $99 \%$ of the chinook salmon migrants passed our trap during spring. This data indicates that most juvenile spring chinook salmon that left the upper rearing areas during fall overwintered in the valley reaches of the Grande Ronde River. Protection and enhancement of habitat in the Grande Ronde Valley should be given high priority to maintain or enhance overwinter survival of juvenile spring chinook salmon that reside in the valley during winter.

The Lostine River trap fished for 281 d between 22 July 1997 and 30 June 1998. Distinct fall and spring migrations were evident (Figure 3), while smaller numbers of salmon were captured during summer and winter (Table 4). The date that the median fall migrant passed the trap was 1 November. The date that the median spring migrant moved past the trap was 25 March and was similar to last year's median of 3 April.

We estimated that a minimum of $15,738 \pm 1,231$ juvenile spring chinook salmon migrants moved out of the Lostine River during MY 98. Seasonal trap efficiencies were 22.8, $34.9,52.3$ and $35.1 \%$ for summer, fall, winter, and spring, respectively. Based on these efficiencies, we estimated that approximately $61 \%(9,459 \pm 1,010)$ of the migrants moved in fall and $34 \%(5,388 \pm 641)$ migrated in spring. In addition, approximately $3 \%(540 \pm 283)$ moved prior to the start of fall and 2\% (262 \pm 56$)$ moved during winter. In MY 98, the majority of the migrants left the Lostine River in fall. In MY 97, we did not begin operating the Lostine River 
trap until 24 October 1996 (week 43). It is not appropriate, therefore, to compare annual abundance or seasonal distribution of migrants in MY 97 with other years.

The Wallowa River trap fished for 221 d between 8 September 1997 and 11 June 1998. Distinct fall and spring migrations were evident at this trap (Figure 3). The dates that the median fall and spring migrants passed the trap were 26 October and 14 April, respectively.

We estimated that a minimum of 22,754 $\pm 2,484$ juvenile spring chinook salmon migrants moved past our trap during MY 98. Seasonal trap efficiency was 19.3, 24.4 and 21.7\% in fall, winter, and spring, respectively. Based on these trap efficiencies, $55 \%(12,100 \pm 1,759)$ of the migrant population moved out of upper rearing areas in fall, $5 \%(1,122 \pm 296)$ in winter, and $40 \%(9,533 \pm 1,728)$ in spring.

The pattern of movement at this trap was very similar to that seen upriver at the Lostine trap. Trap-to-trap travel times suggest Lostine River spring chinook salmon use the valley portion of the Wallowa River primarily as a migration corridor and that fall migrants move below the Wallowa River trap site for overwintering. Travel times between the Lostine trap and the Wallowa trap in fall ranged from 1 to $36 \mathrm{~d}$ with a mean of $4.0 \mathrm{~d}(\mathrm{~N}=72)$.

Mean lengths and weights of juvenile spring chinook salmon captured in the upper Grande Ronde River and PIT-tagged are given in Tables 5 and 6. Mean lengths and weights of juvenile spring chinook salmon captured from Catherine Creek and PIT-tagged are given in Tables 7 and 8. Mean lengths and weights of juvenile spring chinook salmon captured from the Lostine River and PIT-tagged are given in Tables 9 and 10. Length frequency distributions of juvenile spring chinook salmon caught in all traps by migration period are shown in Figures 4 through 8.

No trends for increasing size of migrants over time were evident from weekly mean lengths and weights of salmon at any of the traps (Tables $11-15$ ). This is in contrast to what we have observed in previous years. Migrants captured at the lower Grande Ronde River trap generally were larger than fish captured at the upper Grande Ronde and Catherine Creek traps in MY 98. The mean weekly size of the spring migrating cohort at the lower Grande Ronde trap has been consistently greater than the mean size at the upper traps, suggesting salmon grow substantially during their downstream migration. This idea is supported by size data collected from individuals that were PIT-tagged at the upper traps during spring and recaptured on average one month later at the lower Grande Ronde trap (Table 16). Spring PIT-tagged fish from Catherine Creek grew an average of $16.7 \mathrm{~mm}(\mathrm{SE}=2.99)$ while fish from the upper Grande Ronde grew $7.2 \mathrm{~mm}(\mathrm{SE}=0.90)$.

It does not appear that we can detect spring growth from the Wallowa subbasin trap data. Although the mean weekly length is consistently more than $5 \mathrm{~mm}$ larger at the Wallowa trap than at the Lostine trap, the travel time between traps averages only four days. In addition, no change in size was evident for PIT-tagged fish from the Lostine River (Table 16). Thus, we believe the discrepancy in mean size between the Lostine and Wallowa traps reflects that the Wallowa trap collects larger salmon from other tributary populations in addition to the Lostine River population rather than growth of fish between the Lostine trap and the Wallowa trap. 
Table 5. Fork lengths ( $\mathrm{mm}$ ) of juvenile chinook salmon collected from the upper Grande Ronde River. Winter fish were captured with seines or dipnets in the upper Grande Ronde River from rkm 299 to 323. Fall and spring fish were captured with a rotary screw trap at rkm 299. Min. = minimum, Max. = maximum.

\begin{tabular}{lccccc}
\hline & \multicolumn{5}{c}{ Collected } \\
\cline { 2 - 6 } Group & $N$ & Mean & SE & Min. & Max. \\
\hline Fall & 646 & 82.0 & 0.44 & 59 & 115 \\
Winter & 160 & 75.0 & 0.80 & 57 & 106 \\
Spring & 865 & 86.6 & 0.37 & 64 & 118 \\
\hline \hline Release & \multicolumn{5}{c}{ Tagged and released } \\
group & $N$ & Mean & SE & Min. & Max. \\
\hline Fall & 591 & 82.3 & 0.45 & 59 & 115 \\
Winter & 124 & 71.0 & 0.52 & 57 & 82 \\
Spring & 513 & 89.1 & 0.48 & 65 & 118 \\
\hline
\end{tabular}

Table 6. Weights (g) of juvenile chinook salmon collected from the upper Grande Ronde River. Winter fish were captured with seines or dipnets in the upper Grande Ronde River from rkm 299 to 323. Fall and spring fish were captured with a rotary screw trap at rkm 299. Min. = minimum, Max. $=$ maximum.

\begin{tabular}{lccccc}
\hline & \multicolumn{5}{c}{ Collected } \\
\cline { 2 - 6 } Group & $N$ & Mean & SE & Min. & Max. \\
\hline Fall & 642 & 6.18 & 0.097 & 2.1 & 15.7 \\
Winter & 160 & 4.55 & 0.157 & 2.0 & 12.2 \\
Spring & 862 & 6.78 & 0.088 & 2.0 & 16.3 \\
\hline \hline Release & $N$ & Mean & Tagged and released & \\
group & 589 & 6.22 & SE & Min. & Max. \\
\hline Fall & 124 & 3.78 & 0.101 & 2.1 & 15.7 \\
Winter & 513 & 7.29 & 0.116 & 2.0 & 6.1 \\
Spring & & & 2.0 & 16.2 \\
\hline
\end{tabular}


Table 7. Fork lengths ( $\mathrm{mm}$ ) of juvenile chinook salmon collected from Catherine Creek. Winter fish were captured with seines or dipnets in Catherine Creek from rkm 42 to 50. Fall and spring fish were captured with a rotary screw trap at $\mathrm{rkm} 32$. Min. $=$ minimum, Max. $=$ maximum.

\begin{tabular}{lccccc}
\hline & \multicolumn{5}{c}{ Collected } \\
\cline { 2 - 6 } Group & $N$ & Mean & SE & Min. & Max. \\
\hline Fall & 978 & 87.9 & 0.22 & 52 & 109 \\
Winter & 579 & 89.7 & 0.28 & 69 & 108 \\
Spring & 539 & 93.2 & 0.32 & 67 & 120 \\
\hline \hline Release & \multicolumn{5}{c}{ Tagged and released } \\
group & $N$ & Mean & SE & Min. & Max. \\
\hline Fall & 597 & 88.1 & 0.28 & 65 & 108 \\
Winter & 437 & 89.6 & 0.32 & 70 & 107 \\
Spring & 453 & 93.2 & 0.34 & 70 & 118 \\
\hline
\end{tabular}

Table 8. Weights (g) of juvenile chinook salmon collected from Catherine Creek. Winter fish were captured with seines or dipnets in Catherine Creek from rkm 42 to 50. Fall and spring fish were captured with a rotary screw trap at $\mathrm{rkm} 32$. Min. = minimum, Max. $=$ maximum.

\begin{tabular}{lccccc}
\hline & \multicolumn{5}{c}{ Collected } \\
\cline { 2 - 6 } Group & $N$ & Mean & SE & Min. & Max. \\
\hline Fall & 977 & 7.63 & 0.060 & 1.6 & 14.5 \\
Winter & 578 & 7.65 & 0.075 & 3.5 & 13.6 \\
Spring & 525 & 8.54 & 0.089 & 2.6 & 17.2 \\
\hline \hline Release & & \multicolumn{5}{c}{ Tagged and released } \\
group & $N$ & Mean & SE & Min. & Max. \\
\hline Fall & 596 & 7.74 & 0.078 & 2.4 & 14.1 \\
Winter & 436 & 7.68 & 0.085 & 3.5 & 13.6 \\
Spring & 450 & 8.55 & 0.096 & 3.1 & 17.2 \\
\hline
\end{tabular}


Table 9. Fork lengths ( $\mathrm{mm})$ of juvenile chinook salmon collected from the Lostine River. Winter fish were captured with dipnets in the Lostine River from rkm 5 to 21. Fall and spring fish were captured with a rotary screw trap at rkm 3. Min. $=$ minimum, Max. $=$ maximum.

\begin{tabular}{lrrrrc}
\hline & \multicolumn{5}{c}{ Collected } \\
\cline { 2 - 6 } Group & $N$ & Mean & SE & Min. & Max. \\
\hline Fall & 1348 & 96.9 & 0.22 & 61 & 123 \\
Winter & 132 & 97.6 & 0.86 & 70 & 128 \\
Spring & 857 & 107.4 & 0.46 & 71 & 147 \\
\hline \hline Release & \multicolumn{5}{c}{ Tagged and released } \\
group & $N$ & Mean & SE & Min. & Max. \\
\hline Fall & 498 & 97.9 & 0.35 & 66 & 122 \\
Winter & 505 & 94.6 & 0.36 & 76 & 123 \\
Spring & 470 & 109.1 & 0.63 & 77 & 147 \\
\hline
\end{tabular}

Table 10. Weights (g) of juvenile chinook salmon collected from the Lostine River. Winter fish were captured with dipnets in the Lostine River from rkm 5 to 21. Fall and spring fish were captured with a rotary screw trap at rkm 3. Min. $=$ minimum, Max. $=$ maximum.

\begin{tabular}{lrcccc}
\hline & \multicolumn{5}{c}{ Collected } \\
\cline { 2 - 6 } Group & $N$ & Mean & SE & Min. & Max. \\
\hline Fall & 1217 & 10.71 & 0.08 & 3.4 & 22.8 \\
Winter & 132 & 10.24 & 0.28 & 3.6 & 22.7 \\
Spring & 857 & 14.51 & 0.20 & 3.6 & 38.4 \\
\hline \hline Release & \multicolumn{5}{c}{ Tagged and released } \\
group & $N$ & Mean & SE & Min. & Max. \\
\hline Fall & 426 & 11.20 & 0.21 & 3.4 & 81.8 \\
Winter & 505 & 9.39 & 0.12 & 4.8 & 22.2 \\
Spring & 470 & 15.35 & 0.28 & 6.0 & 38.4 \\
\hline
\end{tabular}




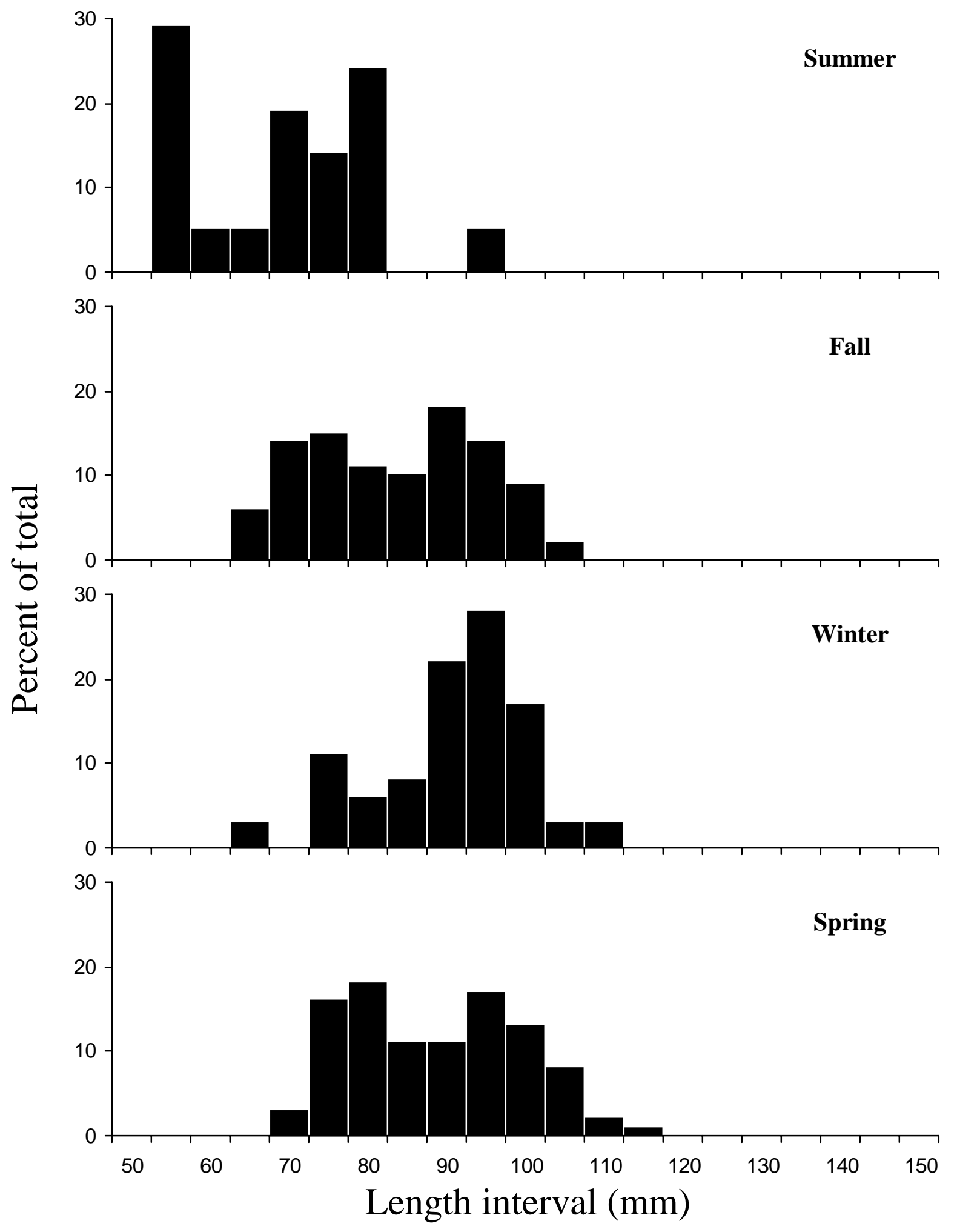

Figure 4. Length frequency distribution (fork length) of juvenile spring chinook salmon migrants captured at the upper Grande Ronde River trap (rkm 164) by seasonal migration period, during the 1998 migration year. 


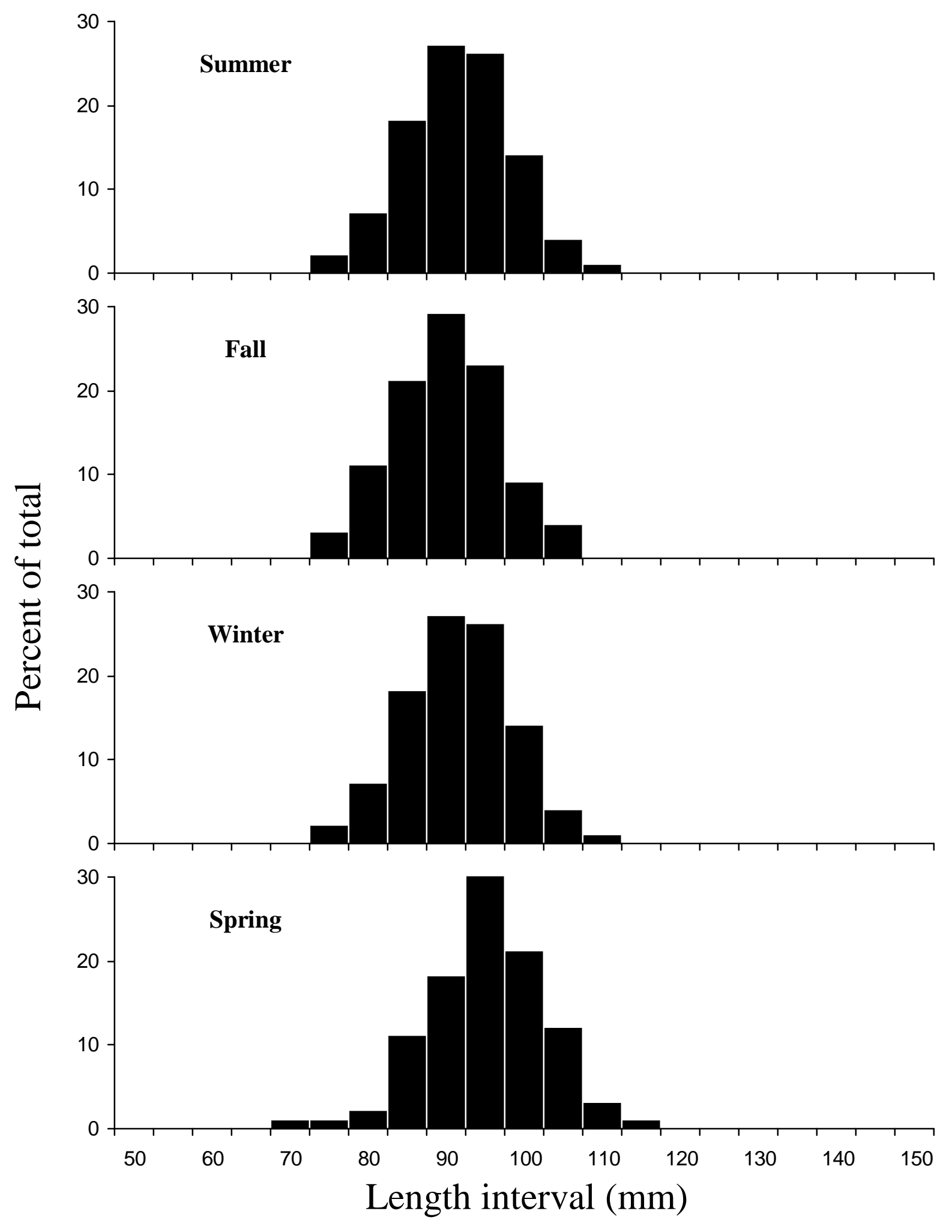

Figure 5. Length frequency distribution (fork length) of juvenile spring chinook salmon migrants captured at the Catherine Creek trap (rkm 32) by seasonal migration period, during the 1998 migration year. 


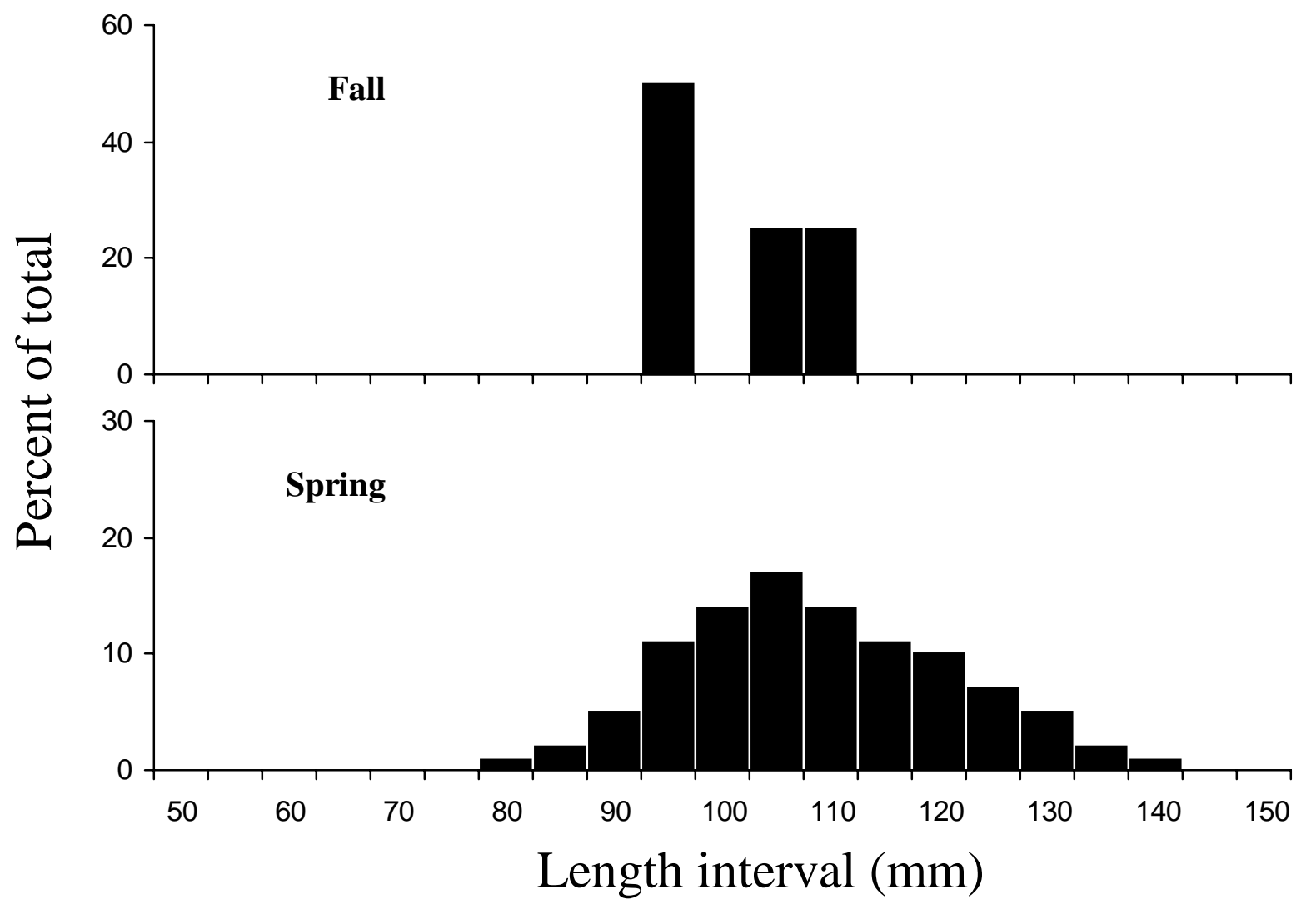

Figure 6. Length frequency distribution (fork length) of juvenile spring chinook salmon migrants captured at the Grande Ronde Valley trap ( $\mathrm{rkm} 299$ ) by seasonal migration period, during the 1998 migration year. 


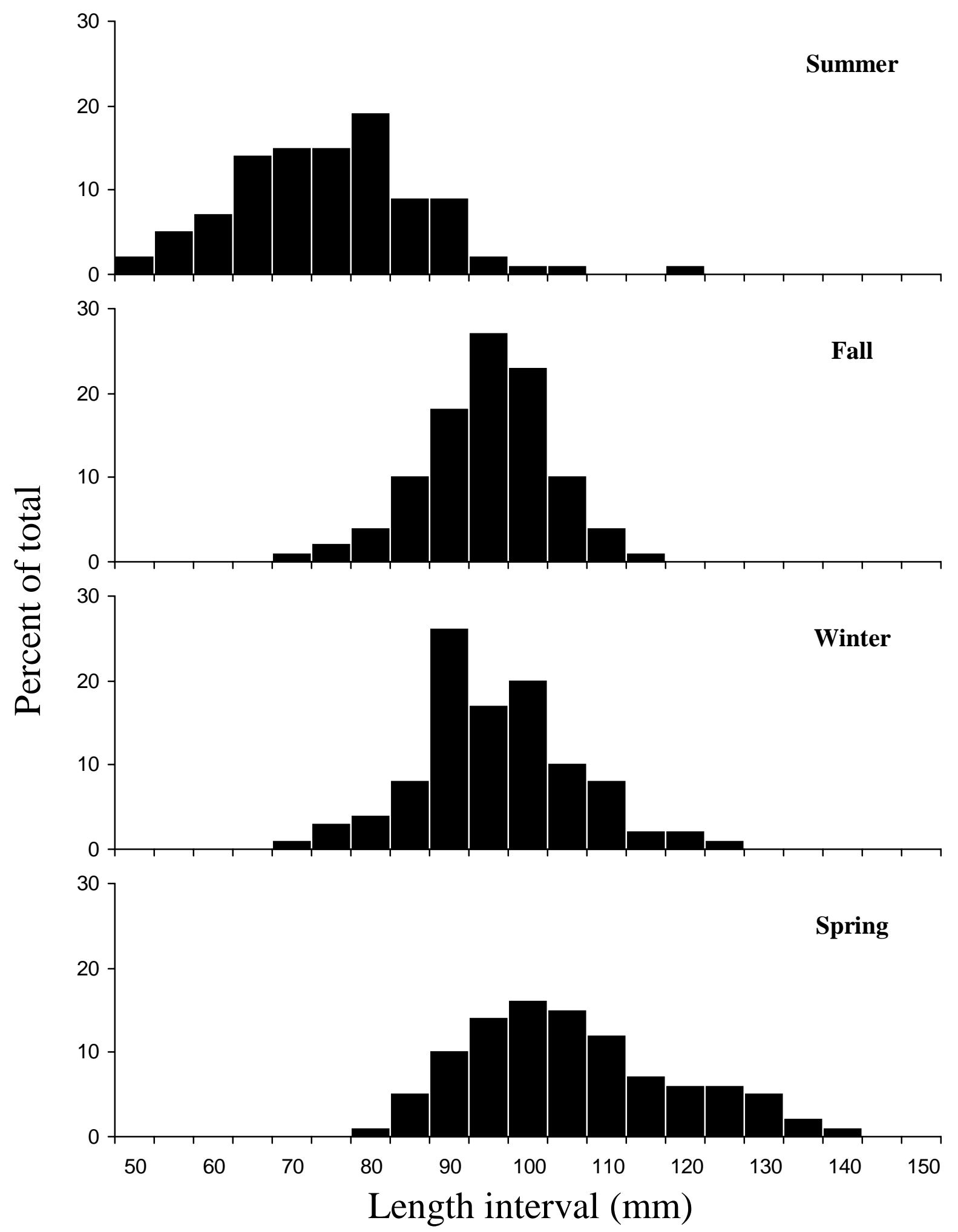

Figure 7. Length frequency distribution (fork length) of juvenile spring chinook salmon migrants captured at the Lostine River trap (rkm 3) by seasonal migration period, during the 1998 migration year. 




Figure 8. Length frequency distribution (fork length) of juvenile spring chinook salmon migrants captured at the Wallowa Valley trap (rkm 27) by seasonal migration period, during the 1998 migration year. 
Table 11. Fork lengths ( $\mathrm{mm}$ ) and weights (g) of juvenile chinook salmon captured by a rotary screw trap at rkm 299 of the Grande Ronde River, weeks 26 to 48, 1997 and weeks 5 to 22, 1998. Min. $=$ minimum, Max. $=$ maximum.

\begin{tabular}{|c|c|c|c|c|c|c|c|c|c|c|}
\hline \multirow{2}{*}{$\begin{array}{l}\text { Year, } \\
\text { week }\end{array}$} & \multicolumn{5}{|c|}{ Length } & \multicolumn{5}{|c|}{ Weight } \\
\hline & $N$ & Mean & SE & Min. & Max. & $N$ & Mean & SE & Min. & Max. \\
\hline \multicolumn{11}{|l|}{ 1997: } \\
\hline 26 & 4 & 52.0 & 0.50 & 51 & 53 & 0 & & & & \\
\hline 27 & 1 & & & 53 & 53 & 0 & & & & \\
\hline 28 & 2 & 56.0 & 0.71 & 55 & 57 & 2 & 2.35 & 0.177 & 2.1 & 2.6 \\
\hline 30 & 2 & 65.5 & 1.06 & 64 & 67 & 0 & & & & \\
\hline 32 & 7 & 74.7 & 1.79 & 67 & 79 & 7 & 5.16 & 0.410 & 3.3 & 6.5 \\
\hline 35 & 1 & & & 74 & 74 & 1 & & & 5.1 & 5.1 \\
\hline 36 & 4 & 78.0 & 4.60 & 70 & 93 & 4 & 5.73 & 1.092 & 3.5 & 9.2 \\
\hline 38 & 5 & 81.4 & 4.13 & 72 & 97 & 5 & 6.95 & 1.041 & 4.1 & 11.2 \\
\hline 39 & 11 & 85.4 & 2.65 & 69 & 98 & 11 & 6.87 & 1.955 & 3.4 & 10.2 \\
\hline 40 & 18 & 81.6 & 2.08 & 64 & 95 & 18 & 6.21 & 1.767 & 3.0 & 9.2 \\
\hline 41 & 75 & 81.9 & 1.12 & 64 & 100 & 75 & 6.12 & 0.245 & 2.2 & 11.3 \\
\hline 42 & 16 & 83.4 & 2.42 & 68 & 98 & 16 & 6.47 & 0.582 & 3.2 & 10.4 \\
\hline 43 & 101 & 83.6 & 1.03 & 61 & 106 & 101 & 6.45 & 0.230 & 2.5 & 13.1 \\
\hline 44 & 241 & 80.0 & 0.68 & 59 & 106 & 237 & 5.77 & 0.151 & 2.1 & 14.7 \\
\hline 45 & 78 & 76.6 & 1.15 & 60 & 101 & 78 & 4.97 & 0.248 & 2.4 & 11.7 \\
\hline 46 & 7 & 83.7 & 3.62 & 69 & 94 & 7 & 6.66 & 0.848 & 3.3 & 8.9 \\
\hline 47 & 72 & 91.0 & 1.29 & 61 & 115 & 72 & 8.10 & 0.309 & 2.4 & 15.7 \\
\hline 48 & 22 & 82.7 & 2.66 & 62 & 112 & 22 & 6.46 & 0.631 & 2.5 & 15.4 \\
\hline
\end{tabular}

1998:

$\begin{array}{rrrrrrrrrrr}5 & 4 & 86.3 & 4.60 & 71 & 94 & 4 & 6.33 & 0.877 & 3.6 & 8.1 \\ 7 & 14 & 87.2 & 2.45 & 71 & 99 & 14 & 6.71 & 0.530 & 3.9 & 9.4 \\ 8 & 18 & 90.6 & 2.32 & 63 & 106 & 18 & 7.78 & 0.536 & 2.4 & 12.2 \\ 10 & 2 & 94.5 & 3.18 & 90 & 99 & 2 & 8.25 & 1.096 & 6.7 & 9.8 \\ & & & & & & & & & & \\ 11 & 213 & 93.2 & 0.65 & 71 & 118 & 213 & 8.31 & 0.167 & 3.5 & 16.2 \\ 12 & 206 & 86.8 & 0.74 & 65 & 115 & 206 & 6.72 & 0.175 & 2.0 & 15.2 \\ 13 & 106 & 83.5 & 1.02 & 65 & 111 & 106 & 5.95 & 0.233 & 2.9 & 13.7 \\ 14 & 106 & 81.6 & 0.97 & 64 & 108 & 105 & 5.51 & 0.215 & 2.2 & 12.7 \\ 15 & 56 & 84.8 & 1.61 & 65 & 118 & 55 & 6.22 & 0.353 & 2.7 & 12.4\end{array}$


Table 11. Continued.

\begin{tabular}{|c|c|c|c|c|c|c|c|c|c|c|}
\hline \multirow{2}{*}{$\begin{array}{l}\text { Year, } \\
\text { week }\end{array}$} & \multicolumn{5}{|c|}{ Length } & \multicolumn{5}{|c|}{ Weight } \\
\hline & $N$ & Mean & SE & Min. & Max. & $N$ & Mean & SE & Min. & Max. \\
\hline \multicolumn{11}{|l|}{ 1998: } \\
\hline 16 & 72 & 83.4 & 1.21 & 69 & 102 & 71 & 5.95 & 0.253 & 2.4 & 10.9 \\
\hline 17 & 41 & 80.2 & 1.20 & 66 & 98 & 41 & 5.69 & 0.276 & 3.0 & 10.3 \\
\hline 19 & 7 & 88.9 & 2.76 & 81 & 105 & 7 & 8.73 & 0.951 & 6.0 & 14.2 \\
\hline 20 & 27 & 83.3 & 0.91 & 75 & 95 & 27 & 6.56 & 0.236 & 4.4 & 9.3 \\
\hline 21 & 17 & 85.2 & 2.32 & 71 & 111 & 17 & 7.36 & 0.705 & 4.1 & 16.3 \\
\hline 22 & 12 & 90.2 & 1.98 & 80 & 102 & 12 & 8.47 & 0.594 & 5.1 & 11.9 \\
\hline
\end{tabular}

Table 12. Fork lengths $(\mathrm{mm})$ and weights $(\mathrm{g})$ of juvenile chinook salmon captured by a rotary screw trap at rkm 32 of Catherine Creek, weeks 30 to 48, 1997 and weeks 1 to 18, 1998. Min. = minimum, Max. = maximum.

\begin{tabular}{|c|c|c|c|c|c|c|c|c|c|c|}
\hline \multirow{2}{*}{$\begin{array}{l}\text { Year, } \\
\text { week }\end{array}$} & \multicolumn{5}{|c|}{ Length } & \multicolumn{5}{|c|}{ Weight } \\
\hline & $N$ & Mean & SE & Min. & Max. & $N$ & Mean & $\mathrm{SE}$ & Min. & Max. \\
\hline \multicolumn{11}{|l|}{ 1997: } \\
\hline 30 & 3 & 72.0 & 3.21 & 67 & 78 & 3 & 4.17 & 0.626 & 3.4 & 5.7 \\
\hline 31 & 9 & 81.3 & 2.55 & 72 & 92 & 9 & 6.33 & 0.593 & 4.0 & 9.6 \\
\hline 32 & 57 & 83.6 & 0.79 & 67 & 99 & 57 & 6.79 & 0.199 & 3.3 & 10.9 \\
\hline 33 & 10 & 82.3 & 1.86 & 71 & 92 & 10 & 6.60 & 0.470 & 4.2 & 10.1 \\
\hline 34 & 9 & 84.7 & 1.81 & 75 & 92 & 9 & 7.71 & 0.620 & 4.5 & 10.6 \\
\hline 35 & 16 & 85.1 & 1.68 & 70 & 96 & 16 & 7.14 & 0.393 & 4.3 & 10.5 \\
\hline 36 & 46 & 85.4 & 0.66 & 72 & 93 & 46 & 7.52 & 0.174 & 5.5 & 10.1 \\
\hline 37 & 34 & 85.9 & 1.10 & 70 & 99 & 31 & 7.35 & 0.332 & 3.4 & 10.9 \\
\hline 38 & 55 & 84.3 & 0.91 & 65 & 96 & 55 & 6.95 & 0.223 & 3.0 & 9.6 \\
\hline 39 & 49 & 89.1 & 0.80 & 75 & 99 & 49 & 8.21 & 0.234 & 4.8 & 11.4 \\
\hline 40 & 124 & 88.6 & 0.64 & 73 & 108 & 124 & 8.03 & 0.189 & 4.1 & 14.1 \\
\hline 41 & 139 & 85.8 & 0.59 & 52 & 101 & 139 & 7.01 & 0.141 & 1.6 & 11.6 \\
\hline 42 & 64 & 89.4 & 0.90 & 76 & 104 & 64 & 8.20 & 0.272 & 4.8 & 13.6 \\
\hline 43 & 244 & 88.8 & 0.41 & 75 & 104 & 244 & 7.91 & 0.114 & 4.2 & 13.3 \\
\hline 44 & 75 & 87.8 & 0.75 & 74 & 109 & 75 & 7.63 & 0.199 & 4.2 & 14.5 \\
\hline
\end{tabular}


Table 12. Continued.

\begin{tabular}{|c|c|c|c|c|c|c|c|c|c|c|}
\hline \multirow{2}{*}{$\begin{array}{l}\text { Year, } \\
\text { week }\end{array}$} & \multicolumn{5}{|c|}{ Length } & \multicolumn{5}{|c|}{ Weight } \\
\hline & $N$ & Mean & $\mathrm{SE}$ & Min. & Max. & $N$ & Mean & $\mathrm{SE}$ & Min. & Max. \\
\hline \multicolumn{11}{|l|}{ 1997: } \\
\hline 45 & 20 & 86.7 & 1.58 & 75 & 96 & 20 & 7.20 & 0.397 & 4.4 & 10.3 \\
\hline 46 & 62 & 88.8 & 0.94 & 67 & 104 & 62 & 7.62 & 0.242 & 2.4 & 12.1 \\
\hline 47 & 117 & 87.4 & 0.63 & 70 & 107 & 116 & 7.13 & 0.170 & 3.4 & 14.0 \\
\hline 48 & 29 & 90.4 & 1.34 & 74 & 102 & 29 & 7.84 & 0.346 & 4.4 & 10.9 \\
\hline \multicolumn{11}{|l|}{ 1998: } \\
\hline 1 & 2 & 82.0 & 8.00 & 74 & 90 & 2 & 5.75 & 1.237 & 4.0 & 7.5 \\
\hline 3 & 40 & 91.9 & 1.12 & 77 & 108 & 40 & 8.31 & 0.304 & 4.0 & 13.4 \\
\hline 4 & 35 & 87.1 & 1.02 & 73 & 96 & 35 & 6.81 & 0.252 & 3.9 & 10.0 \\
\hline 5 & 37 & 90.0 & 1.24 & 74 & 107 & 37 & 7.42 & 0.310 & 4.0 & 13.3 \\
\hline 6 & 28 & 90.7 & 1.33 & 69 & 103 & 28 & 7.59 & 0.328 & 3.8 & 12.2 \\
\hline 7 & 7 & 90.0 & 1.46 & 84 & 96 & 7 & 7.40 & 0.417 & 5.8 & 8.9 \\
\hline 8 & 7 & 94.4 & 2.46 & 83 & 103 & 7 & 8.69 & 0.666 & 5.6 & 11.6 \\
\hline 9 & 89 & 94.3 & 0.78 & 67 & 113 & 89 & 8.64 & 0.227 & 2.6 & 16.0 \\
\hline 10 & 32 & 95.1 & 1.12 & 78 & 107 & 32 & 9.00 & 0.324 & 4.5 & 12.6 \\
\hline 11 & 124 & 92.4 & 0.60 & 74 & 118 & 124 & 8.21 & 0.153 & 3.8 & 13.3 \\
\hline 12 & 104 & 93.4 & 0.64 & 70 & 108 & 104 & 8.49 & 0.174 & 3.3 & 14.1 \\
\hline 13 & 86 & 90.7 & 0.86 & 70 & 105 & 86 & 8.07 & 0.226 & 3.1 & 13.2 \\
\hline 14 & 23 & 94.9 & 1.82 & 82 & 113 & 20 & 8.68 & 0.471 & 5.8 & 13.0 \\
\hline 15 & 16 & 92.9 & 1.76 & 77 & 104 & 16 & 8.69 & 0.464 & 4.6 & 10.9 \\
\hline 16 & 48 & 95.5 & 1.44 & 73 & 120 & 39 & 10.08 & 0.441 & 5.3 & 17.2 \\
\hline 17 & 1 & & & 100 & 100 & 1 & & & 11.7 & 11.7 \\
\hline 18 & 2 & 96.0 & 9.00 & 87 & 105 & 0 & & & & \\
\hline
\end{tabular}


Table 13. Fork lengths $(\mathrm{mm})$ and weights $(\mathrm{g})$ of juvenile chinook salmon captured by a rotary screw trap at rkm 164 of the Grande Ronde River, weeks 43 to 49, 1997 and weeks 8 to 21, 1998. Min. $=$ minimum, Max. $=$ maximum.

\begin{tabular}{|c|c|c|c|c|c|c|c|c|c|c|}
\hline \multirow{2}{*}{$\begin{array}{l}\text { Year, } \\
\text { week }\end{array}$} & \multicolumn{5}{|c|}{ Length } & \multicolumn{5}{|c|}{ Weight } \\
\hline & $N$ & Mean & $\mathrm{SE}$ & Min. & Max. & $N$ & Mean & SE & Min. & Max. \\
\hline \multicolumn{11}{|l|}{ 1997: } \\
\hline 43 & 1 & & & 95 & 95 & 1 & & & 8.9 & 8.9 \\
\hline 46 & 1 & & & 95 & 95 & 1 & & & 9.1 & 9.1 \\
\hline 47 & 1 & & & 107 & 107 & 1 & & & 14.5 & 14.5 \\
\hline 49 & 1 & & & 105 & 105 & 1 & & & 11.5 & 11.5 \\
\hline \multicolumn{11}{|l|}{ 1998: } \\
\hline 8 & 16 & 107.4 & 3.53 & 84 & 136 & 16 & 13.51 & 1.350 & 5.6 & 24.5 \\
\hline 9 & 42 & 110.1 & 1.49 & 84 & 135 & 42 & 14.42 & 0.612 & 6.3 & 26.9 \\
\hline 10 & 32 & 109.2 & 2.30 & 76 & 126 & 32 & 14.57 & 0.844 & 4.9 & 21.1 \\
\hline 11 & 16 & 107.0 & 3.18 & 88 & 130 & 16 & 13.55 & 1.277 & 6.6 & 23.3 \\
\hline 12 & 21 & 106.6 & 2.35 & 87 & 127 & 21 & 13.03 & 0.994 & 6.7 & 22.3 \\
\hline 13 & 28 & 106.4 & 2.21 & 87 & 131 & 28 & 13.27 & 0.847 & 7.7 & 24.4 \\
\hline 14 & 92 & 104.6 & 1.13 & 90 & 142 & 92 & 12.18 & 0.471 & 6.8 & 31.4 \\
\hline 15 & 141 & 107.0 & 1.15 & 80 & 149 & 141 & 14.04 & 0.484 & 6.0 & 36.3 \\
\hline 16 & 218 & 109.8 & 0.84 & 80 & 141 & 199 & 14.81 & 0.351 & 5.8 & 29.1 \\
\hline 17 & 123 & 105.3 & 1.20 & 79 & 153 & 123 & 13.04 & 0.460 & 4.8 & 39.7 \\
\hline 18 & 40 & 102.8 & 2.18 & 76 & 126 & 40 & 12.75 & 0.808 & 4.8 & 25.3 \\
\hline 19 & 9 & 103.7 & 3.65 & 91 & 130 & 9 & 13.59 & 1.686 & 9.3 & 27.1 \\
\hline 20 & 38 & 106.8 & 2.04 & 84 & 130 & 38 & 14.48 & 0.819 & 6.4 & 23.0 \\
\hline 21 & 32 & 104.8 & 2.08 & 86 & 126 & 32 & 13.00 & 0.786 & 7.5 & 22.3 \\
\hline
\end{tabular}


Table 14. Fork lengths $(\mathrm{mm})$ and weights $(\mathrm{g})$ of juvenile chinook salmon captured by a rotary screw trap at rkm 3 of the Lostine River, weeks 25 to 52, 1997 and weeks 1 to 18, 1998. Min. = minimum, Max. = maximum.

\begin{tabular}{|c|c|c|c|c|c|c|c|c|c|c|}
\hline \multirow{2}{*}{$\begin{array}{l}\text { Year, } \\
\text { week }\end{array}$} & \multicolumn{5}{|c|}{ Length } & \multicolumn{5}{|c|}{ Weight } \\
\hline & $N$ & Mean & SE & Min. & Max. & $N$ & Mean & $\mathrm{SE}$ & Min. & Max. \\
\hline \multicolumn{11}{|l|}{ 1997: } \\
\hline 25 & 6 & 59.2 & 3.64 & 46 & 71 & 6 & 2.78 & 0.477 & 1.1 & 4.4 \\
\hline 26 & 8 & 52.3 & 3.68 & 32 & 64 & 8 & 1.93 & 0.328 & 0.3 & 3.4 \\
\hline 27 & 11 & 65.7 & 2.13 & 56 & 82 & 11 & 3.56 & 0.372 & 2.4 & 6.3 \\
\hline 28 & 16 & 65.5 & 2.08 & 51 & 83 & 16 & 3.64 & 0.343 & 1.8 & 7.2 \\
\hline 29 & 8 & 70.5 & 4.21 & 58 & 95 & 8 & 4.23 & 0.941 & 2.1 & 10.4 \\
\hline 30 & 30 & 74.4 & 2.35 & 50 & 104 & 30 & 5.49 & 0.522 & 1.8 & 14.4 \\
\hline 31 & 32 & 76.1 & 1.64 & 54 & 93 & 32 & 5.85 & 0.362 & 2.0 & 10.5 \\
\hline 32 & 20 & 75.5 & 1.93 & 60 & 103 & 20 & 5.93 & 0.537 & 2.6 & 14.4 \\
\hline 33 & 7 & 80.3 & 3.12 & 69 & 89 & 7 & 6.56 & 0.722 & 4.2 & 8.6 \\
\hline 34 & 2 & 95.5 & 20.50 & 75 & 116 & 2 & 12.40 & 7.600 & 4.8 & 20.0 \\
\hline 36 & 5 & 94.6 & 4.06 & 87 & 110 & 5 & 10.80 & 1.718 & 8.5 & 17.6 \\
\hline 37 & 26 & 91.4 & 2.20 & 69 & 123 & 26 & 9.74 & 0.746 & 3.6 & 22.5 \\
\hline 38 & 36 & 93.5 & 1.22 & 78 & 110 & 36 & 10.11 & 0.407 & 5.8 & 17.0 \\
\hline 39 & 94 & 98.5 & 0.84 & 71 & 122 & 94 & 11.77 & 0.284 & 4.4 & 22.8 \\
\hline 40 & 191 & 99.3 & 0.55 & 66 & 117 & 191 & 11.93 & 0.193 & 3.4 & 20.8 \\
\hline 41 & 62 & 98.3 & 0.90 & 83 & 116 & 62 & 11.53 & 0.351 & 6.2 & 19.2 \\
\hline 42 & 47 & 97.3 & 1.19 & 77 & 118 & 47 & 10.72 & 0.374 & 5.6 & 17.0 \\
\hline 43 & 113 & 97.6 & 0.70 & 76 & 122 & 113 & 11.26 & 0.663 & 4.3 & 16.6 \\
\hline 44 & 199 & 96.9 & 0.54 & 71 & 117 & 199 & 10.41 & 0.179 & 4.0 & 19.9 \\
\hline 45 & 88 & 94.7 & 0.92 & 72 & 115 & 88 & 10.84 & 0.255 & 5.0 & 16.4 \\
\hline 46 & 85 & 97.9 & 0.76 & 80 & 110 & 85 & 10.57 & 0.253 & 5.2 & 17.5 \\
\hline 47 & 217 & 95.7 & 0.55 & 61 & 115 & 217 & 9.79 & 0.196 & 3.5 & 20.3 \\
\hline 48 & 51 & 98.3 & 1.33 & 81 & 121 & 51 & 9.60 & 0.330 & 5.3 & 15.0 \\
\hline 49 & 87 & 95.7 & 0.97 & 76 & 118 & 87 & 9.88 & 0.303 & 3.6 & 17.8 \\
\hline 50 & 23 & 96.2 & 1.62 & 79 & 109 & 23 & 10.70 & 0.876 & 5.8 & 22.7 \\
\hline 51 & 11 & 92.5 & 2.37 & 81 & 107 & 11 & 9.48 & 0.822 & 5.9 & 15.9 \\
\hline 52 & 13 & 92.5 & 2.28 & 79 & 106 & 13 & 11.22 & 0.970 & 6.8 & 20.0 \\
\hline
\end{tabular}


Table 14. Continued.

\begin{tabular}{|c|c|c|c|c|c|c|c|c|c|c|}
\hline \multirow{2}{*}{$\begin{array}{l}\text { Year, } \\
\text { week }\end{array}$} & \multicolumn{5}{|c|}{ Length } & \multicolumn{5}{|c|}{ Weight } \\
\hline & $N$ & Mean & SE & Min. & Max. & $N$ & Mean & $\mathrm{SE}$ & Min. & Max. \\
\hline \multicolumn{11}{|l|}{ 1998: } \\
\hline 1 & 20 & 95.4 & 2.37 & 75 & 108 & 20 & 12.04 & 0.664 & 7.9 & 16.8 \\
\hline 2 & 17 & 94.1 & 1.97 & 79 & 111 & 17 & 12.31 & 0.870 & 8.1 & 22.2 \\
\hline 3 & 11 & 99.1 & 3.03 & 88 & 116 & 11 & 10.55 & 0.800 & 8.0 & 15.6 \\
\hline 4 & 8 & 96.6 & 3.21 & 80 & 110 & 8 & 10.36 & 0.501 & 7.1 & 11.5 \\
\hline 5 & 10 & 101.2 & 2.19 & 91 & 111 & 10 & 10.80 & 0.654 & 7.9 & 14.2 \\
\hline 6 & 5 & 96.6 & 3.23 & 89 & 106 & 5 & 9.38 & 1.029 & 7.2 & 12.2 \\
\hline 7 & 15 & 95.3 & 2.99 & 70 & 114 & 15 & 9.35 & 0.789 & 3.6 & 15.0 \\
\hline 8 & 33 & 98.5 & 1.80 & 83 & 128 & 33 & 10.48 & 0.653 & 5.8 & 22.7 \\
\hline 9 & 31 & 102.3 & 1.55 & 85 & 120 & 31 & 11.90 & 0.567 & 6.8 & 20.0 \\
\hline 10 & 58 & 103.8 & 1.26 & 89 & 127 & 58 & 12.37 & 0.482 & 7.1 & 22.2 \\
\hline 11 & 95 & 102.8 & 0.91 & 85 & 124 & 95 & 12.01 & 0.320 & 6.3 & 20.9 \\
\hline 12 & 184 & 102.4 & 0.71 & 77 & 132 & 184 & 12.11 & 0.257 & 5.2 & 25.0 \\
\hline 13 & 86 & 101.0 & 1.12 & 80 & 130 & 86 & 11.66 & 0.414 & 5.8 & 25.7 \\
\hline 14 & 52 & 114.0 & 2.21 & 79 & 141 & 52 & 17.85 & 0.988 & 6.4 & 32.2 \\
\hline 15 & 126 & 120.6 & 1.19 & 77 & 147 & 126 & 20.76 & 0.566 & 6.1 & 38.4 \\
\hline 16 & 126 & 110.0 & 1.17 & 83 & 142 & 126 & 15.69 & 0.518 & 6.3 & 30.8 \\
\hline 17 & 98 & 106.6 & 1.34 & 71 & 147 & 98 & 14.58 & 0.548 & 3.6 & 34.0 \\
\hline 18 & 14 & 101.6 & 2.93 & 90 & 119 & 14 & 13.10 & 1.178 & 8.1 & 19.2 \\
\hline
\end{tabular}


Table 15. Fork lengths $(\mathrm{mm})$ and weights $(\mathrm{g})$ of juvenile chinook salmon captured by a rotary screw trap at rkm 27 of the Wallowa River, weeks 37 to 52, 1997 and weeks 1 to 21, 1998. Min. $=$ minimum, Max. $=$ maximum.

\begin{tabular}{|c|c|c|c|c|c|c|c|c|c|c|}
\hline \multirow{2}{*}{$\begin{array}{l}\text { Year, } \\
\text { week }\end{array}$} & \multicolumn{5}{|c|}{ Length } & \multicolumn{5}{|c|}{ Weight } \\
\hline & $N$ & Mean & $\mathrm{SE}$ & Min. & Max. & $N$ & Mean & SE & Min. & Max. \\
\hline \multicolumn{11}{|l|}{ 1997: } \\
\hline 37 & 3 & 99.3 & 5.70 & 88 & 106 & 3 & 12.23 & 2.218 & 7.8 & 14.6 \\
\hline 38 & 3 & 103.3 & 2.33 & 97 & 107 & 3 & 13.77 & 1.074 & 11.8 & 15.5 \\
\hline 39 & 35 & 105.0 & 1.35 & 92 & 136 & 35 & 14.46 & 0.605 & 9.4 & 29.6 \\
\hline 40 & 177 & 103.3 & 0.63 & 72 & 134 & 177 & 13.58 & 0.272 & 4.5 & 31.0 \\
\hline 41 & 104 & 106.2 & 0.77 & 83 & 128 & 104 & 14.62 & 0.333 & 6.4 & 25.1 \\
\hline 42 & 96 & 105.2 & 0.90 & 86 & 127 & 96 & 13.82 & 0.366 & 7.5 & 23.9 \\
\hline 43 & 111 & 105.0 & 0.98 & 83 & 132 & 64 & 13.10 & 0.481 & 6.4 & 29.6 \\
\hline 44 & 38 & 102.9 & 1.24 & 90 & 123 & 38 & 12.91 & 0.497 & 8.3 & 21.7 \\
\hline 45 & 89 & 104.5 & 1.03 & 86 & 131 & 89 & 13.30 & 0.419 & 6.7 & 28.1 \\
\hline 46 & 130 & 107.8 & 0.89 & 83 & 142 & 130 & 14.60 & 0.396 & 6.8 & 36.1 \\
\hline 47 & 100 & 106.1 & 0.96 & 83 & 129 & 100 & 13.71 & 0.420 & 6.3 & 34.2 \\
\hline 48 & 54 & 106.3 & 1.55 & 79 & 129 & 54 & 13.78 & 0.599 & 6.1 & 23.5 \\
\hline 49 & 93 & 104.6 & 0.98 & 78 & 127 & 93 & 12.95 & 0.360 & 5.1 & 21.5 \\
\hline 50 & 44 & 109.5 & 1.40 & 94 & 128 & 44 & 14.56 & 0.577 & 8.8 & 22.8 \\
\hline 51 & 38 & 105.9 & 1.39 & 82 & 123 & 38 & 13.17 & 0.525 & 6.1 & 19.7 \\
\hline 52 & 34 & 107.4 & 1.51 & 93 & 137 & 34 & 13.69 & 0.630 & 8.8 & 27.6 \\
\hline \multicolumn{11}{|l|}{ 1998: } \\
\hline 1 & 13 & 107.8 & 3.09 & 94 & 130 & 13 & 13.71 & 1.277 & 8.7 & 24.4 \\
\hline 2 & 8 & 102.9 & 2.00 & 97 & 114 & 8 & 11.55 & 0.666 & 10.0 & 15.6 \\
\hline 3 & 32 & 105.7 & 1.32 & 87 & 117 & 32 & 12.95 & 0.464 & 7.9 & 17.5 \\
\hline 4 & 27 & 106.0 & 1.39 & 93 & 122 & 27 & 12.86 & 0.515 & 8.4 & 19.4 \\
\hline 5 & 36 & 106.3 & 1.08 & 89 & 118 & 36 & 12.75 & 0.380 & 7.0 & 17.1 \\
\hline 6 & 17 & 107.5 & 2.07 & 92 & 120 & 17 & 13.37 & 0.770 & 8.1 & 18.8 \\
\hline 7 & 11 & 115.0 & 2.88 & 100 & 131 & 11 & 16.35 & 1.165 & 9.9 & 22.8 \\
\hline 8 & 19 & 105.9 & 2.69 & 87 & 128 & 19 & 13.22 & 1.059 & 6.6 & 22.2 \\
\hline 9 & 37 & 107.8 & 1.62 & 86 & 129 & 37 & 13.75 & 0.625 & 7.2 & 23.1 \\
\hline 10 & 40 & 110.4 & 1.60 & 92 & 142 & 40 & 14.80 & 0.750 & 8.3 & 34.4 \\
\hline
\end{tabular}


Table 15. Continued.

\begin{tabular}{|c|c|c|c|c|c|c|c|c|c|c|}
\hline \multirow{2}{*}{$\begin{array}{l}\text { Year, } \\
\text { week }\end{array}$} & \multicolumn{5}{|c|}{ Length } & \multicolumn{5}{|c|}{ Weight } \\
\hline & $N$ & Mean & $\mathrm{SE}$ & Min. & Max. & $N$ & Mean & $\mathrm{SE}$ & Min. & Max. \\
\hline \multicolumn{11}{|l|}{ 1998: } \\
\hline 11 & 92 & 111.8 & 0.98 & 83 & 145 & 91 & 15.95 & 0.443 & 7.0 & 34.8 \\
\hline 12 & 89 & 111.3 & 1.04 & 88 & 134 & 89 & 15.83 & 0.440 & 8.6 & 27.8 \\
\hline 13 & 91 & 109.3 & 1.21 & 77 & 129 & 91 & 15.00 & 0.453 & 5.2 & 23.3 \\
\hline 14 & 63 & 113.0 & 1.35 & 85 & 147 & 63 & 16.39 & 0.682 & 6.5 & 34.9 \\
\hline 15 & 174 & 117.8 & 0.81 & 88 & 147 & 174 & 18.65 & 0.398 & 7.1 & 34.6 \\
\hline 16 & 114 & 115.1 & 0.93 & 89 & 143 & 114 & 17.89 & 0.444 & 7.7 & 32.8 \\
\hline 17 & 60 & 111.4 & 1.47 & 88 & 133 & 60 & 16.47 & 0.617 & 7.4 & 29.6 \\
\hline 18 & 18 & 106.4 & 2.96 & 84 & 126 & 18 & 14.36 & 1.107 & 6.7 & 21.4 \\
\hline 19 & 10 & 103.9 & 4.29 & 83 & 119 & 10 & 14.37 & 1.832 & 6.6 & 21.6 \\
\hline 20 & 4 & 102.3 & 7.83 & 85 & 123 & 4 & 13.18 & 2.753 & 7.3 & 20.6 \\
\hline 21 & 3 & 91.7 & 4.81 & 85 & 101 & 3 & 9.27 & 1.386 & 7.2 & 11.9 \\
\hline
\end{tabular}

Table 16. Mean fork lengths $(\mathrm{mm})$ by tag group of juvenile spring chinook salmon PIT-tagged on the upper Grande Ronde River, Catherine Creek, and Lostine River and recaptured at the Grande Ronde Valley or Wallowa Valley traps during spring. Standard errors are in parentheses.

\begin{tabular}{lrcr}
\hline Trap site of tagging, & \multicolumn{3}{c}{ Mean fork length } \\
\cline { 2 - 4 } tag group & $N$ & Tagging & Recapture \\
\hline Upper Grande Ronde & & & \\
$\quad$ Fall & 30 & $83.4(2.30)$ & $101.7(1.70)$ \\
$\quad$ Winter & 2 & $76.0(0.71)$ & $98.0(4.95)$ \\
$\quad$ Spring & 52 & $92.0(1.29)$ & $99.2(1.19)$ \\
Catherine Creek & & & \\
$\quad$ Summer & 6 & $84.5(3.42)$ & $116.2(2.53)$ \\
$\quad$ Fall & 13 & $90.7(0.96)$ & $116.7(1.96)$ \\
$\quad$ Winter & 4 & $92.3(0.65)$ & $106.0(1.70)$ \\
$\quad$ Spring & 13 & $98.8(2.09)$ & $115.5(2.05)$ \\
Lostine River & & & $110.2(2.89)$ \\
$\quad$ Fall & 11 & $96.3(1.53)$ & $108.4(2.14)$ \\
$\quad$ Winter & 23 & $97.1(2.11)$ & $112.9(1.52)$ \\
$\quad$ Spring & 72 & $112.0(1.56)$ & \\
\hline
\end{tabular}




\section{Migration Timing and Survival to Lower Granite Dam}

\section{Juvenile Trapping Studies}

At the upper Grande Ronde River trap, we PIT-tagged 592 fall- and 513 spring-migrating chinook salmon juveniles that were not previously tagged. At the Catherine Creek trap, we PITtagged 598 fall- and 453 spring-migrating spring chinook salmon juveniles that were not previously tagged. During winter, we captured and PIT-tagged an additional 124 and 438 juveniles from rearing areas upstream for the upper Grande Ronde River and Catherine Creek traps, respectively. At the Lostine River trap, we PIT-tagged 500 fall- and 466 spring-migrating juvenile chinook salmon that were not previously tagged. During winter, we captured and PITtagged an additional 504 juveniles from rearing areas above the trap.

PIT-tagged fish from the upper Grande Ronde River $(N=203)$ were detected at Lower Granite Dam from 4 April to 26 June 1998, with 50\% of the fish passing the dam by 1 May 1998 (Figure 9). PIT-tagged fish from Catherine Creek $(N=283)$ were detected at Lower Granite Dam from 3 April to 26 June 1998, with 50\% of the fish passing the dam by 8 May 1998 (Figure 10). These dates are within the migration windows observed for fish from the upper Grande Ronde and Catherine Creek in past years. PIT-tagged fish from the Lostine River $(N=265)$ were detected at Lower Granite Dam from 31 March through 26 May 1998, with 50\% of the fish passing the dam by 27 April 1998 (Figure 11). The timing of the Lostine River fish in MY 98 was similar to that observed in MY 98 with respect to the first, last, and median fish passing the dam.

Travel times to Lower Granite Dam for fish tagged during the spring migration at the upper Grande Ronde River trap ranged from 25 to $71 \mathrm{~d}$ with a mean of $49 \mathrm{~d}(N=116)$. Travel times for fish tagged at the Catherine Creek trap ranged from 12 to $87 \mathrm{~d}$ with a mean of $57 \mathrm{~d}(\mathrm{~N}=$ 109). Travel times for fish tagged at the Lostine River trap ranged from 6 to $59 \mathrm{~d}$ with a mean of $21 \mathrm{~d}(N=183)$. Data from the past three years indicate travel times have remained relatively constant for fish from these three populations. Fish from the Grande Ronde River population have exhibited the most variation, with means ranging from 49 to $57 \mathrm{~d}$.

Median arrival dates at Lower Granite Dam for fish PIT-tagged at the upper Grande Ronde River trap during fall, winter, and spring were 27 April, 5 June, and 5 May 1998, respectively (Figure 9). Medians for fish PIT-tagged at the Catherine Creek trap were 1 May (fall), 11 May (winter), and 21 May (spring) (Figure 10). Medians for fish PIT-tagged at the Lostine River trap were 21 April (fall), 29 April (winter), and 28 April (spring )(Figure 11). As in past years, the earliest of the upper Grande Ronde River, Catherine Creek, and Lostine River fish to be detected were those that were tagged during fall and overwintered in lower rearing areas. 


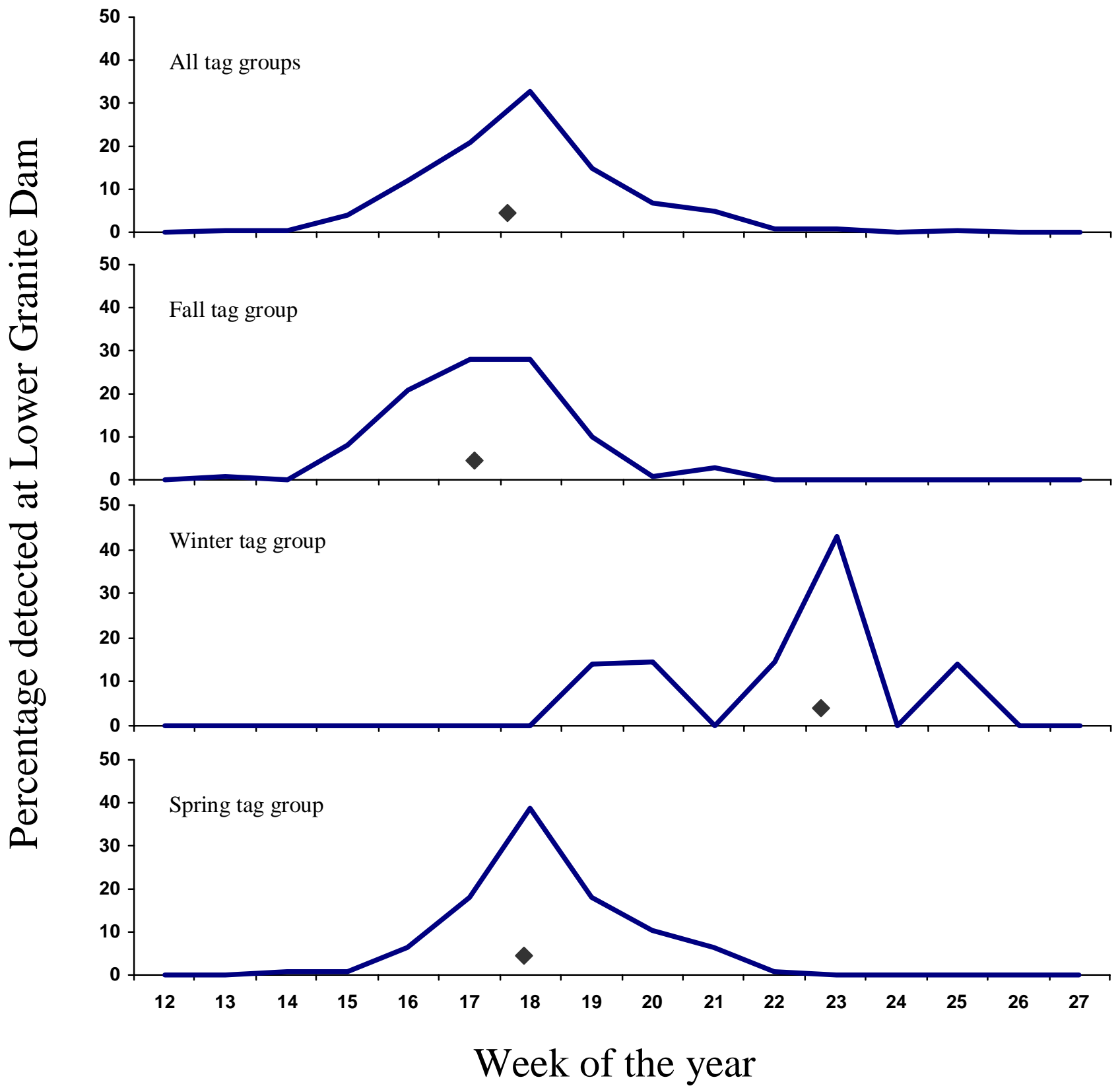

Figure 9. Migration timing at Lower Granite Dam for juvenile spring chinook salmon PITtagged on the upper Grande Ronde River by tag group, during the 1998 migration year. $\bullet=$ median arrival date. Data were expanded for spillway flow. 


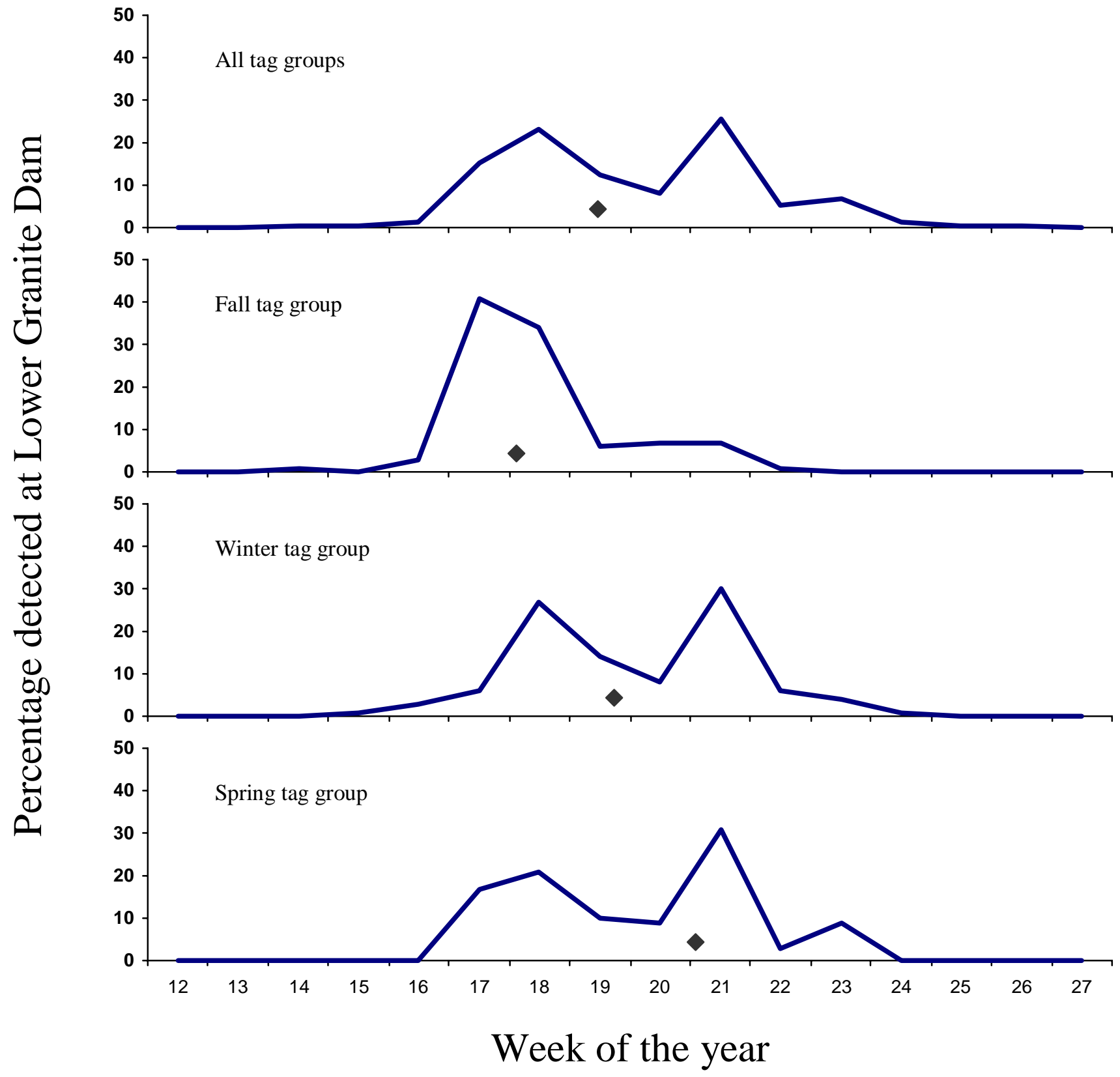

Figure 10. Migration timing at Lower Granite Dam for juvenile spring chinook salmon PITtagged on Catherine Creek by tag group, during the 1998 migration year. $\bullet=$ median arrival date. Data were expanded for spillway flow. 


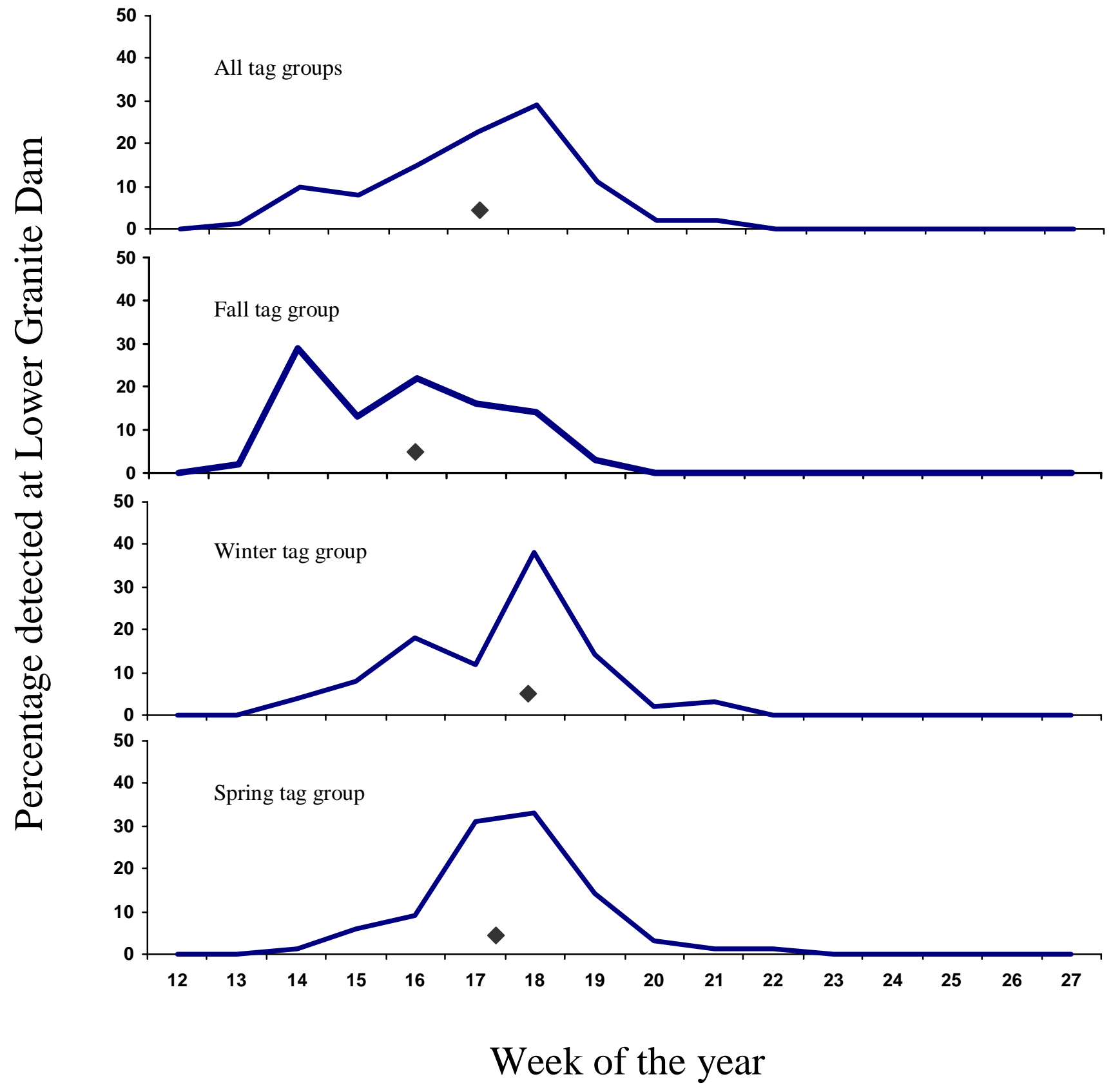

Figure 11. Migration timing at Lower Granite Dam for juvenile spring chinook salmon PITtagged on the Lostine River by tag group, during the 1998 migration year. $\bullet=$ median arrival date. Data were expanded for spillway flow. 
Detection rates by tag group for upper Grande Ronde River fish ranged from $11 \%$ for fish tagged during the winter to $47 \%$ for fish tagged during the spring migration (Table 17). We anticipated that spring-tagged fish would have the highest detection rate since this group is the only tag group not subject to overwinter mortality after tagging. Fall-tagged fish from the upper Grande Ronde were detected at a higher rate than winter-tagged fish, suggesting better overwinter survival for fish that moved out of the upper rearing areas and overwintered in the Grande Ronde Valley habitat. This finding is consistent with past years when we have been able to compare fall- and winter-tagged fish. A comparison of the detection rates of winter- and spring-tagged fish from the upper Grande Ronde indicated that overwinter survival of fish remaining in upper rearing areas was approximately $22 \%$ for the 1996 brood year. This rate is comparable to past estimates that have ranged from 25 to $33 \%$.

Detection rates by tag group for Catherine Creek fish ranged from 19\% for fish tagged during the fall to $46 \%$ for fish tagged during the spring migration (Table 17). Fall-tagged fish were detected at a slightly lower rate than winter-tagged fish, suggesting similar overwinter survival for fish that remained in upper rearing areas and those that overwintered in the Grande Ronde Valley habitat. There appears to be no distinct pattern for survival advantage among Catherine Creek fish. In some years it appears to be a better strategy to overwinter in upper rearing areas, in other years the opposite is true, and in still others, there appears to be no difference in the survival of fish overwintering in upper versus lower rearing areas. Comparing detection rates of winter- and spring-tagged fish from Catherine Creek indicates that overwinter

Table 17. Detection rates of juvenile chinook salmon PIT-tagged on the upper Grande Ronde River, Catherine Creek, and the Lostine River by group and dam site during the 1998 migration year. Detection rates are presented as a percentage of the total fish released.

\begin{tabular}{|c|c|c|c|c|c|c|c|c|}
\hline $\begin{array}{c}\text { Stream and } \\
\text { group }\end{array}$ & $\begin{array}{l}\text { Number } \\
\text { released }\end{array}$ & $\begin{array}{c}\text { Lower } \\
\text { Granite }\end{array}$ & $\begin{array}{l}\text { Little } \\
\text { Goose } \\
\end{array}$ & $\begin{array}{l}\text { Lower } \\
\text { Mon. }\end{array}$ & McNary & $\begin{array}{l}\text { John } \\
\text { Day } \\
\end{array}$ & Bonn. & Total \\
\hline \multicolumn{9}{|c|}{ Grande Ronde River } \\
\hline Fall & 592 & 13.7 & 6.4 & 3.6 & 0.3 & 1.0 & 0.3 & 25.3 \\
\hline Winter & 124 & 4.9 & 3.2 & 1.6 & 0.8 & 0.0 & 0.0 & 10.5 \\
\hline Spring & 513 & 22.6 & 16.4 & 5.1 & 1.6 & 1.2 & 0.0 & 46.8 \\
\hline \multicolumn{9}{|c|}{ Catherine Creek } \\
\hline Fall & 598 & 10.0 & 5.0 & 2.2 & 0.7 & 1.2 & 0.3 & 19.4 \\
\hline Winter & 438 & 13.1 & 5.7 & 3.2 & 0.9 & 0.2 & 0.0 & 23.1 \\
\hline Spring & 453 & 24.0 & 12.4 & 6.2 & 2.2 & 0.7 & 0.4 & 45.9 \\
\hline \multicolumn{9}{|c|}{ Lostine River } \\
\hline Fall & 500 & 22.0 & 7.6 & 2.4 & 5.6 & 0.4 & 0.6 & 38.6 \\
\hline Winter & 504 & 19.0 & 6.2 & 3.0 & 1.8 & 0.4 & 0.6 & 30.9 \\
\hline Spring & 466 & 39.3 & 21.2 & 6.0 & 2.6 & 1.1 & 0.2 & 70.4 \\
\hline
\end{tabular}


survival of fish remaining in the upper rearing areas was approximately $50 \%$ for BY 96 . This rate is comparable with the BY 93 estimate of $53 \%$ and is considerably greater than the BY 94 and BY 95 estimates of 32 and 19\%, respectively.

Detection rates by tag group for Lostine River fish ranged from $31 \%$ for fish tagged during the winter to $70 \%$ for fish tagged during the spring migration (Table 17). Fall-tagged fish from the Lostine River were detected at a higher rate than winter-tagged fish, suggesting better survival for fish that moved out of the upper rearing areas and overwintered downstream, perhaps in the Wallowa canyon or the lower Grande Ronde River. Comparing detection rates of winter- and spring-tagged fish from the upper Lostine River indicates that overwinter survival of fish remaining in the upper rearing areas was approximately $44 \%$ in BY 96 . This rate is comparable to the BY 95 estimate of $53 \%$.

A preliminary look at interannual patterns of migration and dam detections for fish from Catherine Creek and the Lostine River indicates fish that exhibit the predominant migration strategy in any given year are detected at the dams at a higher rate than fish that exhibit the alternative migration strategies. In years when a majority of the population migrated out of upper rearing areas in the fall, higher survival indices were observed for the fall group than for the group of fish that remained in upper rearing areas for winter. In contrast, in years when the proportions of fish outmigrating in fall and overwintering in upper rearing areas for the winter were similar, survival indices for the two groups have been similar. This pattern is not evident for the upper Grande Ronde population. In that population, a majority of fish consistently remain in upper rearing areas for the winter, even in years when survival indices were greater for fish that outmigrated in the fall. These patterns warrant further consideration and analyses that we will conduct after MY 99.

In all populations, fish that leave upper rearing areas in the fall arrive at Lower Granite Dam earlier than fish that leave in the spring. As environmental conditions in the Snake and Columbia rivers vary from year to year, the survival rates of fish utilizing the different early life history strategies may vary as fish arrive at the dams during different periods of the migration season. These differences point out the need to maintain the diversity of life history strategies observed in the spring chinook salmon of the Grande Ronde River Basin.

\section{Parr Studies}

Juvenile chinook salmon captured with seines and PIT-tagged on Catherine Creek and the Imnaha and Minam rivers in summer 1997 were detected at Lower Granite Dam over a 63 d period beginning on 3 April 1998 and ending on 4 June 1998 (Figure 12). The migratory period of individual populations ranged from $42 \mathrm{~d}$ (Catherine Creek ) to $58 \mathrm{~d}$ (Minam River) in length. Median dates of migration ranged from 29 April (Imnaha and Minam River populations) to 17 May (Catherine Creek population). Migration timing differed significantly among populations $(\mathrm{P}=0.0001)$. Fish from the Imnaha and Minam rivers passed the dam significantly earlier than fish from Catherine Creek. There was no significant difference between fish from the Imnaha and Minam rivers. 
Our findings in 1998 were consistent with past observations (Sankovich et al. 1996, in press; Walters et al. 1997). For each population, the median date of migration in 1998 fell within the range of medians observed from 1993 to 1997. Furthermore, comparisons of timing between populations yielded results that had been obtained in at least some past years. Fish from the Minam and Imnaha rivers migrated through the dam with similar timing (no significant difference) in 1998 and in one of five previous years of study (Minam River fish were earlier in the remaining years). Fish from Catherine Creek migrated through the dam later than fish from the Imnaha and Minam rivers in 1998 and in three of five and all of five previous years of study, respectively. The differences we have observed among populations demonstrate the need to manage the hydrosystem so as to maximize survival throughout the entire migratory period of Snake River spring/summer salmon smolts. Maintenance of the remaining populations, their specific life histories, and unique genetic characteristics is critical to the continued persistence of chinook salmon in northeast Oregon and elsewhere in the Snake River Basin.

Of the parr PIT-tagged on Catherine Creek and the Minam and Imnaha rivers in 1997, $16.4,20.5$, and $28.1 \%$ were detected in the hydrosystem as smolts in 1998 (Table 18). These detection rates were among the highest observed thus far for each population, despite relatively high levels of spill at the dams and a theoretical reduction in the probability of detection of PITtagged fish.

During the 1998 migration, there were no detections of any age 2+ smolts that had been PIT-tagged as parr on Catherine Creek, and the Imnaha, Lostine, Minam, and Wenaha rivers in summer 1996. A total of 2,780 parr were PIT-tagged and released in those streams in 1996 (Sankovich et al. 1996). To date, the information we have gathered regarding age $2+$ smolts indicates this life history is rare among northeast Oregon chinook salmon. Of 24,727 parr PITtagged on Catherine Creek and the Grande Ronde, Imnaha, Lostine, Minam, and Wenaha rivers from 1992 to 1996 (Walters et al. 1992, 1997; Sankovich et al. 1996, in press), only 11 (0.04\%) were detected in the hydrosystem as age $2+$ smolts. Eight of the fish originated in the upper Grande Ronde River and all but one were detected in 1995. This may indicate that the age 2+ smolt life history is expressed at varying levels among populations and is dependent upon conditions which occur infrequently. Further investigation will be required to address these issues. 


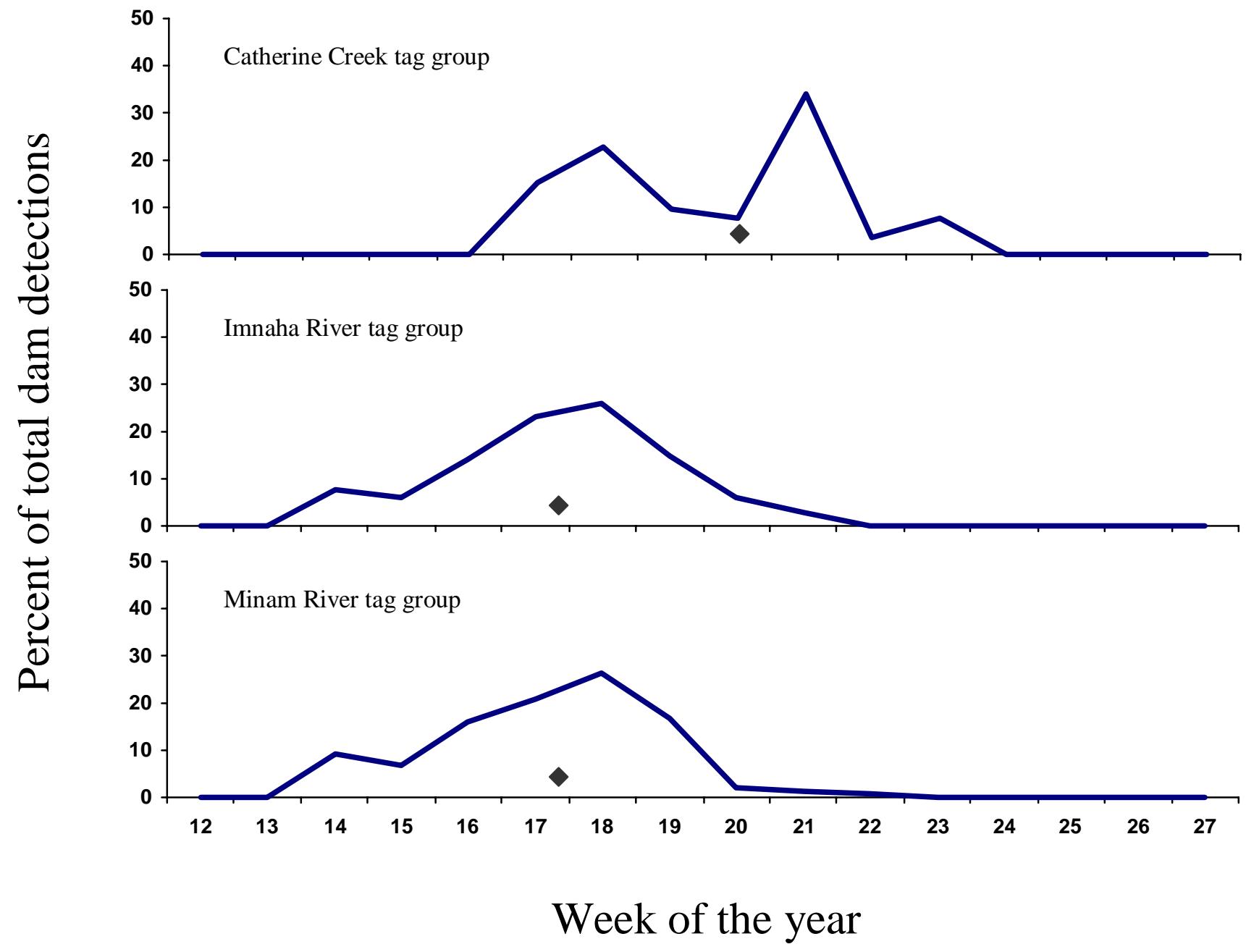

Figure 12. Migration timing at Lower Granite Dam for juvenile spring chinook salmon PITtagged as parr during summer 1997. = median arrival date. Data were expanded for spillway flow. 
One question that needs to be resolved regarding age $2+$ smolts is whether they arise from immature or mature age $1+$ parr, or both. We assumed they arise from immature age $1+$ parr and, therefore, assessed the frequency of the age $2+$ smolt life history in part by determining the abundance of immature, age 1+ parr in Catherine Creek and the Lostine River in 1998. Our research indicated that no such fish were present in those streams in 1998 (see Results and Discussion, Egg-to-Parr Survival, Abundance, and Age Composition of Parr in Summer). This result is not surprising given the apparent rarity of the age $2+$ smolt life history. However, the question that arises is this: Can we conclude from our findings that no age $1+$ parr were on a course to become age 2+ smolts, or to do so, would information on the fate of mature, age 1+ parr also be required? Ricker (1972), who cited two studies (Gebhards 1960 and Burck 1967), suggested that maturation of age 1+ parr is always followed by death. It is conceivable, however, that some mature age 1+ parr recondition and migrate seaward the following spring. This has been shown to occur for mature, age 0+ parr (Ricker 1972). Furthermore, at our upriver traps on Catherine Creek and the Lostine and upper Grande Ronde rivers, we regularly capture mature, age 1+ parr that appear outwardly to be in excellent condition, weeks after the spawning season. In the future, it may be prudent to attempt to determine the fate of these fish.

Table 18. Detection rates in 1998 of chinook salmon PIT-tagged as parr on Catherine Creek and the Imnaha and Minam rivers in 1997.

\begin{tabular}{|c|c|c|c|c|c|c|c|c|}
\hline Stream & $\begin{array}{l}\text { Number } \\
\text { released }\end{array}$ & $\begin{array}{l}\text { Lower } \\
\text { Granite }\end{array}$ & $\begin{array}{l}\text { Little } \\
\text { Goose }\end{array}$ & $\begin{array}{l}\text { Lower } \\
\text { Mon. }\end{array}$ & McNary & $\begin{array}{l}\text { John } \\
\text { Day }\end{array}$ & Bonn. & Total \\
\hline Catherine $\mathrm{Cr}$. & 495 & 8.7 & 4.9 & 2.6 & 0.2 & 0.0 & 0.0 & 16.4 \\
\hline Imnaha R. & 998 & 15.9 & 6.8 & 3.7 & 1.2 & 0.4 & 0.0 & 28.1 \\
\hline Minam R. & 1,010 & 12.2 & 5.2 & 2.2 & 0.5 & 0.5 & 0.0 & 20.5 \\
\hline
\end{tabular}

\section{Habitat Utilization}

We surveyed 79 habitat units in $29 \mathrm{rkm}$ of Catherine Creek during the winter and observed 401 chinook salmon parr. Chinook salmon were observed in all habitat types except rapids with boulders, and were most abundant in alcoves (Table 19). Juvenile chinook salmon were generally found in low velocity habitat types during winter surveys. We surveyed 91 habitat units in $23 \mathrm{rkm}$ during winter surveys on the Lostine River and observed 243 spring chinook salmon parr. Parr were most abundant in backwater pools and were generally found in low velocity habitat types (Table 20). We surveyed 100 habitat units in $32 \mathrm{rkm}$ of the Lostine River during summer surveys and observed 1,283 spring chinook salmon parr rearing from Turkey Flat Campground to Williamson Campground (rkm 39-30) and from Pole Bridge Picnic Area to the mouth (rkm 23-0). Parr were observed in all habitat types and were most abundant in backwater and dammed pools (Table 21). Parr were generally found in low velocity habitat types. Only one class (1995 BY) of chinook salmon parr were identified during winter counts conducted in January and February of 1997. Summer counts were conducted on the Lostine River from mid-July through early August 1998. Very few mature chinook salmon parr were observed and they were, therefore, not included in density tables. 
Chinook salmon parr were more abundant in pools than glides or riffles during both summer and winter surveys. Maintenance and/or enhancement of existing pool habitat should be given priority in habitat restoration programs. In addition, increasing habitat diversity should be an important component of habitat management for threatened chinook salmon populations in northeast Oregon streams.

Table 19. Density (fish/100 $\mathrm{m}^{2}$ ) of chinook salmon parr in Catherine Creek (rkm 18-19 and rkm 27-46) and mean water velocity (m/s) by habitat type during winter 1998.

\begin{tabular}{lrrc}
\hline Habitat type & $N$ & Density & Water velocity \\
\hline Pools: & & & \\
Alcove & 1 & 126.87 & 0.00 \\
Backwater & 2 & 13.89 & 0.00 \\
Dammed & 2 & 5.19 & 0.31 \\
Lateral scour & 22 & 15.12 & 0.26 \\
Plunge & 2 & 2.86 & 0.31 \\
Straight scour & 21 & 10.24 & 0.27 \\
Glide & 1 & 1.60 & 0.36 \\
Riffle & 17 & 0.51 & 0.56 \\
Riffle with pockets & 8 & 0.60 & 0.38 \\
Rapid with boulders & 3 & 0.00 & 0.89 \\
\hline
\end{tabular}

Table 20. Density (fish/100 $\mathrm{m}^{2}$ ) of chinook salmon parr in the Lostine River (rkm 0-23) and mean water velocity $(\mathrm{m} / \mathrm{s})$ by habitat type during winter 1998 .

\begin{tabular}{lrrc}
\hline Habitat type & $N$ & Density & Water velocity \\
\hline Pools: & & & \\
$\quad$ Backwater & 12 & 32.40 & 0.425 \\
Isolated & 9 & 25.38 & 0.004 \\
Lateral scour & 13 & 21.15 & 2.363 \\
Plunge & 4 & 4.85 & 1.486 \\
Straight scour & 10 & 15.68 & 2.396 \\
Glide & 14 & 10.10 & 2.701 \\
Riffle & 11 & 8.28 & 4.781 \\
Riffle with pockets & 8 & 1.88 & 3.664 \\
Rapid with boulders & 10 & 0.00 & 7.761 \\
\hline
\end{tabular}


Table 21. Density (fish/100 $\mathrm{m}^{2}$ ) of chinook salmon parr in the Lostine River (rkm 0-23 and rkm 30-39) and mean water velocity (m/s) by habitat type during summer 1998.

\begin{tabular}{lrrc}
\hline Habitat type & $N$ & Density & Water velocity \\
\hline Pools: & & & \\
Backwater & 17 & 15.66 & -0.033 \\
Beaver dam & 3 & 6.38 & 0.044 \\
Dammed & 1 & 18.16 & 0.160 \\
Lateral scour & 23 & 13.86 & 0.334 \\
Plunge & 2 & 10.38 & 0.378 \\
Straight scour & 8 & 7.86 & 0.378 \\
Glide & 12 & 7.05 & 0.408 \\
Riffle & 16 & 3.47 & 0.571 \\
Riffle with pockets & 13 & 1.31 & 0.588 \\
Rapid with boulders & 5 & 1.44 & 0.838 \\
\hline
\end{tabular}

\section{Future Directions}

We will continue this early life history study of spring chinook salmon in Catherine Creek and the upper Grande Ronde, Lostine, and Wallowa rivers. In MY 2000, we will begin to piece together the components to build a life history model for spring chinook salmon in our study streams. In addition, we will begin to investigate the life history of summer steelhead in the Grande Ronde River Basin. 


\section{REFERENCES}

Bisson, P. A., J. L. Neilson, R. A. Palmason, and L. E. Grove. 1982. A system of naming habitat types in small streams, with examples of habitat utilization by salmonids during low stream flow. Pages 62-73 in N. B. Armantrout, editor. Acquisition and utilization of aquatic habitat inventory information. American Fisheries Society, Bethesda, MD.

Bryson, D. 1993. Northeast Oregon Hatchery Grande Ronde River Management Plan. Final Report. Bonneville Power Administration, Portland, OR.

Burck, W. A. 1993. Life history of spring chinook salmon in Lookingglass Creek, Oregon. Oregon Department of Fish and Wildlife, Information Reports 94-1, Portland.

Burck, W. A. 1967. Mature stream-reared spring chinook salmon. Oregon Fish Commission Research Briefs 13(1):128.

Daniel, W. W. 1990. Applied Nonparametric Statistics, 2nd edition. PWS-Kent Publishing Company, Boston.

Efron, B., and R. Tibshirani. 1986. Bootstrap methods for standard errors, confidence intervals, and other measures of statistical accuracy. Statistical Science 1:54-77.

Gebhards, S. V. 1960. Biological notes on precocious male chinook salmon in Salmon River drainage. Progressive Fish-Culturist 22(3):121-123.

Giorgi, A. E., G. A. Swan, W. S. Zaugg, T. C. Corley and T. Y. Barila. 1988. The susceptibility of chinook salmon smolts to bypass systems at hydroelectric dams. North American Journal of Fisheries Management 8:25-29.

Hart, P. J. B., and T. J. Pitcher. 1969. Field trials of fish marking using a jet inoculator. Journal of Fish Biology 1:383-385.

Hutchings, J. A., and R. A. Myers. 1985. Mating between anadromous and nonanadromous Atlantic salmon, Salmo salar. Canadian Journal of Zoology 63:2219-2221.

Hutchings, J. A., and R. A. Myers. 1988. Mating success of alternative maturation phenotypes in male Atlantic salmon, Salmo salar. Oecologia (Berl.) 75:169-174.

Johnson, G. E., R. L. Johnson, E. Kudera, C. Sullivan. 1997. Fixed-location hydroacoustic evaluation of the prototype surface bypass and collector at Lower Granite Dam in 1996. Final Report. U.S. Army Corps of Engineers, Walla Walla, WA.

Jonasson, B. C., R. W. Carmichael, and M. Keefe. 1996. Investigations into the early life history of naturally produced spring chinook salmon in the Grande Ronde River Basin. . Annual Progress Report. Bonneville Power Administration, Portland, OR. 
Jonasson, B. C., J. V. Tranquilli, M. Keefe, and R. W. Carmichael. 1997. Investigations into the early life history of naturally produced spring chinook salmon in the Grande Ronde River Basin. Annual Progress Report. Bonneville Power Administration, Portland, OR.

Keefe, M., D. J. Anderson, R. W. Carmichael, and B. C. Jonasson. 1995. Early life history study of Grande Ronde River Basin chinook salmon. Annual Progress Report. Bonneville Power Administration, Portland, OR.

Keefe, M., R. W. Carmichael, B. C. Jonasson, R. T. Messmer, and T. A. Whitesel. 1994. Investigations into the life history of spring chinook salmon in the Grande Ronde River Basin. Annual Progress Report. Bonneville Power Administration, Portland, OR.

Kuehl, S. 1986. Hydroacoustic evaluation of fish collection efficiency at Lower Granite Dam in spring 1985. Final Report to U.S. Army Corps of Engineers, Walla Walla, WA.

Matthews, G. M., J. R. Harmon, S. Achord, O. W. Johnson, and L. A. Kubin. 1990. Evaluation of transportation of juvenile salmonids and related research on the Columbia and Snake rivers, 1989. Report of the U.S. Army Corps of Engineers, Contract DACW68-84H0034. National Marine Fisheries Service, Seattle.

Matthews, G. M., S. Achord, J. R. Harmon, O. W. Johnson, D. M. Marsh, B. P. Sandford, N. N. Paasch, K. W. McIntyre, and K. L. Thomas. 1992. Evaluation of transportation of juvenile salmonids and related research on the Columbia and Snake rivers, 1990. Report of the U.S. Army Corps of Engineers, Contract DACW68-84-H0034. National Marine Fisheries Service, Seattle.

Nickelson, T. E., J. D. Rodgers, S. L. Johnson, and M. F. Solazzi. 1992. Seasonal changes in habitat use by juvenile coho salmon (Oncorhynchus kisutch) in Oregon coastal streams. Canadian Journal of Fisheries and Aquatic Sciences 49:783-789.

NWPPC (Northwest Power Planning Council). 1992. Strategy for salmon, Volume VII.

ODFW (Oregon Department of Fish and Wildlife). 1990. Grande Ronde River Subbasin Salmon and Steelhead Production Plan. Oregon Department of Fish and Wildlife, Portland, OR.

Prentice, E. F, D. L. Park, T. A. Flagg, and S. McCutcheon. 1986. A study to determine the biological feasibility of a new fish tagging system, 1985-1986. Annual Progress Report. Bonneville Power Administration, Portland OR.

Prentice, E. F., T. A. Flagg, C. S. McCutcheon, D. F. Brastow, and D. C. Cross. 1990. Equipment, methods, and an automated data-entry station for PIT tagging. American Fisheries Society Symposium 7:335-340. 
Ricker, W. E. 1972. Heredity and environmental factors affecting certain salmonid populations. Pages 19-160 in R.C. Simon and P.A. Larkin, editors. The stock concept in Pacific salmon. H. R. MacMillan lectures in fisheries, University of British Columbia, Vancouver.

Ricker, W. E. 1975. Computation and interpretation of biological statistics of fish populations. Fisheries Research Board of Canada Bulletin 191.

Rodgers, J. D., M. F. Solazzi, S. L. Johnson, and M. A. Buckman. 1992. Comparison of three techniques to estimate juvenile coho salmon populations in small streams. North American Journal of Fisheries Management 12:79-86.

Rohlf, F. J. and R. R. Sokal. 1995. Statistical Tables, 3rd edition. W. H. Freeman and Company, New York.

Sankovich, P., R. W. Carmichael, and M. Keefe. 1995. Smolt migration characteristics and mainstem Snake and Columbia River detection rates of Grande Ronde and Imnaha River naturally produced spring chinook salmon. Annual Progress Report. Bonneville Power Administration, Portland, OR.

Sankovich, P. M., R. W. Carmichael, and M. Keefe. 1996. Smolt migration characteristics and mainstem Snake and Columbia river detection rates of PIT-tagged Grande Ronde and Imnaha river naturally produced spring chinook salmon. Annual Progress Report. Oregon Department of Fish and Wildlife, Portland, OR.

Sankovich, P., R. W. Carmichael, and M. Keefe. (in press). Smolt migration characteristics and mainstem Snake and Columbia River detection rates of Grande Ronde and Imnaha River naturally produced spring chinook salmon. Annual Progress Report. Bonneville Power Administration, Portland, OR.

Snake River Recovery Team. 1993. Draft Snake River salmon recovery plan recommendations. National Marine Fisheries Service, Portland, OR.

Swan, G. A., R. F. Krcma, and F. J. Ossiander. 1986. Continuing studies to improve and evaluate juvenile collection at Lower Granite Dam, 1985. Report to U. S. Army Corps of Engineers, Portland, OR.

Thedinga, J. F., M. L. Murphy, S. W. Johnson, J. M. Lorenz, and K. V. Koski. 1994. Determination of salmonid smolt yield with rotary-screw traps in the Situk River, Alaska, to predict effects of glacial flooding. North American Journal of Fisheries Management 14:837-851.

Thorpe, J. E., and R. I. G. Morgan. 1980. Growth-rate and smolting-rate of progeny of male Atlantic salmon parr, Salmo Salar L. Journal of Fish Biology 17:451-459. 
USACE (United States Army Corps of Engineers). 1975. Lower Snake River Fish and Wildlife Compensation Plan Special Report. U. S. Army Corps of Engineers, Walla Walla, WA.

USFS (United States Forest Service) and six co-author agencies. 1992. Upper Grande Ronde River Anadromous Fish Habitat Restoration and Monitoring Plan. U. S. Forest Service, Wallowa-Whitman National Forest, Baker, OR.

Walters, T. R., R. W. Carmichael, and M. Keefe. 1992. Smolt migration characteristics and parr-to-smolt survival of naturally produced spring chinook salmon in the Grande Ronde and Imnaha river subbasins. Annual Progress Report, Oregon Department of Fish and Wildlife, Portland, OR.

Walters, T. R., R. W. Carmichael, and M. Keefe. 1993. Smolt migration characteristics and mainstem Snake and Columbia River detection rates of Grande Ronde and Imnaha River naturally produced spring chinook salmon. Annual Progress Report, Oregon Department of Fish and Wildlife, Portland, OR.

Walters, T. R., R. W. Carmichael, and M. Keefe. 1994. Smolt migration characteristics and mainstem Snake and Columbia river detection rates of PIT-tagged Grande Ronde and Imnaha river naturally produced spring chinook salmon. Annual Progress Report. Oregon Department of Fish and Wildlife, Portland, OR.

Walters, T. R., R. W. Carmichael, M. Keefe, and P. Sankovich. 1997. Smolt migration characteristics and mainstem Snake and Columbia River detection rates of Grande Ronde and Imnaha River naturally produced spring chinook salmon. Annual Progress Report 1993, 1994, and 1995. Bonneville Power Administration, Portland, OR. 